\title{
Hydroclimatology of the Missouri River Basin $\mathfrak{O}$
}

\author{
ERIKA K. WISE \\ Department of Geography, University of North Carolina at Chapel Hill, Chapel Hill, North Carolina
}

CONNIE A. WOODHOUSE

School of Geography and Development, The University of Arizona, Tucson, Arizona

GREGORY J. MCCABE

Denver Federal Center, U.S. Geological Survey, Denver, Colorado

GREGORY T. PEDERSON

Northern Rocky Mountain Science Center, U.S. Geological Survey, Bozeman, Montana

JEANNINE-MARIE ST-JACQUES

Concordia University, Montreal, Quebec, Canada

(Manuscript received 14 August 2017, in final form 6 November 2017)

\begin{abstract}
Despite the importance of the Missouri River for navigation, recreation, habitat, hydroelectric power, and agriculture, relatively little is known about the basic hydroclimatology of the Missouri River basin (MRB). This is of particular concern given the droughts and floods that have occurred over the past several decades and the potential future exacerbation of these extremes by climate change. Here, observed and modeled hydroclimatic data and estimated natural flow records in the MRB are used to 1) assess the major source regions of MRB flow, 2) describe the climatic controls on streamflow in the upper and lower basins, and 3) investigate trends over the instrumental period. Analyses indicate that $72 \%$ of MRB runoff is generated by the headwaters in the upper basin and by the lowest portion of the basin near the mouth. Spring precipitation and temperature and winter precipitation impacted by changes in zonal versus meridional flow from the Pacific Ocean play key roles in surface water supply variability in the upper basin. Lower basin flow is significantly correlated with precipitation in late spring and early summer, indicative of Atlantic-influenced circulation variability affecting the flow of moisture from the Gulf of Mexico. Although increases in precipitation in the lower basin are currently overriding the effects of warming temperatures on total MRB flow, the upper basin's long-term trend toward decreasing flows, reduction in snow versus rain fraction, and warming spring temperatures suggest that the upper basin may less often provide important flow supplements to the lower basin in the future.
\end{abstract}

\section{Introduction}

Described as an "unpredictable river in an unpredictable landscape" (Galat et al. 2005, p. 431), the 3726-km-long Missouri River (Fig. 1) flows through a

Supplemental information related to this paper is available at the Journals Online website: https://doi.org/10.1175/JHM-D-170155.s1.

Corresponding author: Prof. Erika K. Wise, ekwise@email.unc. edu wide variety of climatic, geologic, and topographic zones from its headwaters at the Continental Divide to its confluence with the Mississippi River, traversing parts of the Rocky Mountain, Interior Plains, and Interior Highlands physiographic provinces (Lettenmaier et al. 1999; Galat et al. 2005). The Missouri River basin (MRB) covers a 1.37 million $\mathrm{km}^{2}$ area that includes parts of 10 states in the conterminous United States, two Canadian provinces, and more than 20 Native American tribal lands (Mehta et al. 2013). The MRB is a globally important food-producing region, responsible for nearly 


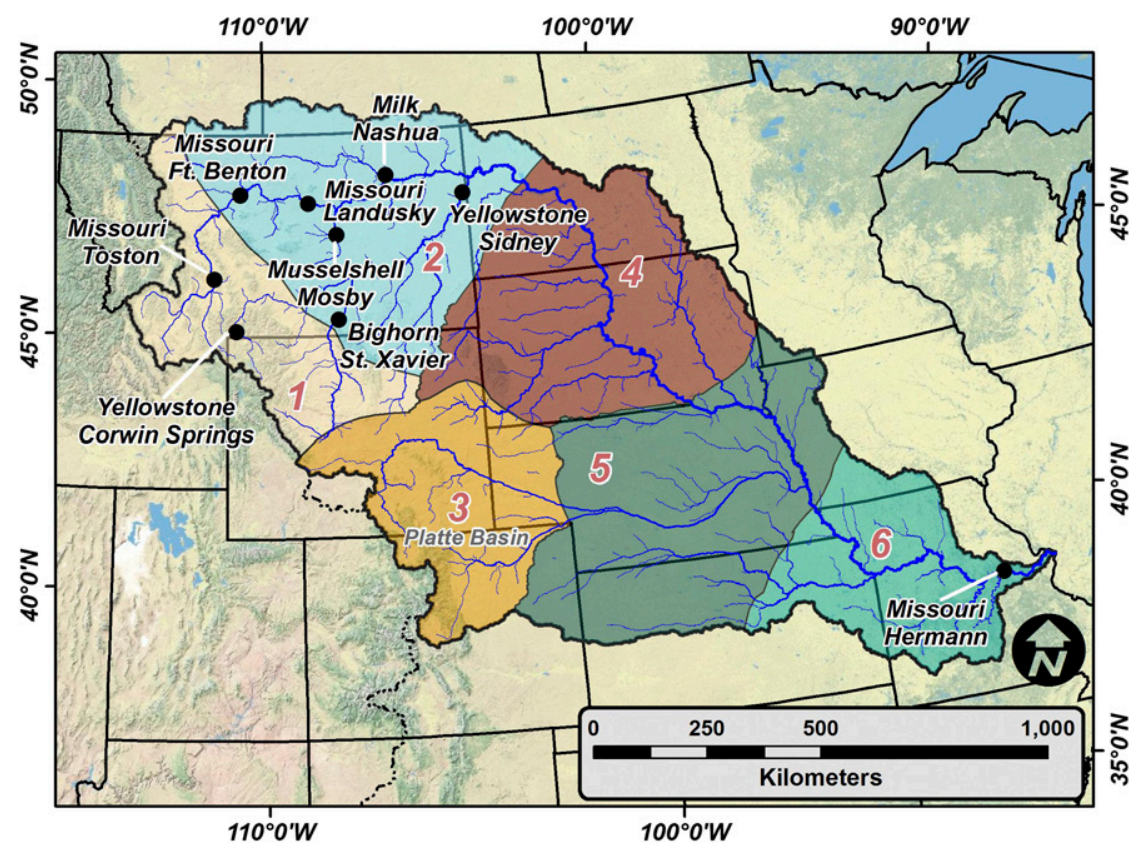

FIG. 1. The MRB mapped with hydroclimatic subregions and the major naturalized streamflow gauges used in the study. The six labeled subregions (red numbers) were identified and grouped based on shared variability in monthly precipitation as described in section 3 a.

half of U.S. wheat production, among other crops (Mehta et al. 2013). In addition to agriculture, users of the MRB depend on the system for drinking water, industrial needs, hydroelectricity generation, navigation, recreation, and fish and wildlife habitats. Although its highest headwaters are free-flowing, the majority of the Missouri River is heavily managed, with six major dams along the main stem (Mehta et al. 2013).

Both droughts and floods are of concern in the MRB, which extends from the semiarid, orographically influenced continental climate of the upper basin to the temperate, semihumid climate of the lower basin (Lettenmaier et al. 1999). Drought periods such as the 1950s and 1980s resulted in insufficient inflows for recreation and navigation and caused tensions between upstream and downstream users (Mehta et al. 2011). In the upper MRB, many basins, including the international St. Mary and Milk River tributaries, are already stressed by overallocation of water. Compounding this issue is the fact that Native American tribes and Canada may claim additional historic water rights for allocation in the near future (U.S. Bureau of Reclamation 2012). Too much water, though, can impose threats on farming and housing when high precipitation requires major releases from dams (Mehta et al. 2011). The MRB has experienced numerous large flooding events over the past several decades (Qiao et al. 2014). Recent years have been defined by severe back-to-back flood and drought events, with 2011 registering as a particularly notable flood year due to infrastructure and agriculture losses (Hoerling et al. 2013; Haj et al. 2014).

There are concerns that hydroclimate variability in the MRB has been increasing over the twentieth century and will continue to be exacerbated by future climate change (Livneh et al. 2016). The general pattern has been toward more precipitation, more streamflow, and more interannual variability (Livneh et al. 2016; Olsen et al. 1999; Qiao et al. 2014). Nine of the 10 largest flood events in the upper MRB have occurred since 1970 (Livneh et al. 2016). Over the past 50 years, trend analysis indicates that annual flow in the western and southern parts of the MRB has decreased while flows in the eastern regions have increased (Norton et al. 2014). The MRB as a whole is projected to become warmer and wetter over the twenty-first century, but it is unclear whether the increase in temperature or the increase in precipitation will be the dominant factor affecting future flow: although precipitation is expected to increase, particularly in winter, the projection of a $3^{\circ} \mathrm{C}$ increase in temperature will increase potential evapotranspiration and result in a shift from snow to rain during cool season months (Qiao et al. 2014). This warming has led investigators to suggest that earlier, slower snowmelt could reduce streamflow in the summer months (Barnhart et al. 2016; Qiao et al. 2014), which would 
have major impacts on agriculture, navigation, and aquatic species of conservation concern such as the endangered pallid sturgeon (Scaphirhynchus albus).

Despite the importance of the basin and the concerns over future climate change-related impacts, relatively little is known about the basic hydroclimatology of the MRB. The wide area covered by the MRB includes regions influenced by warm and moist Gulf of Mexico air, cool and moist air from the Pacific, cold and dry air from the polar regions, and warm and dry air from northern Mexico (Galat et al. 2005). The basin is generally assumed to be differentiated by the upper basin, which is driven by snowmelt, and the lower basin, which is influenced by spring and summer precipitation (e.g., Najibi et al. 2017). Research on causes of flooding has indicated that runoff generation generally starts during March and peaks in June, due primarily to Rocky Mountain snowmelt in the upper basin and late spring precipitation in the lower basin (Galat et al. 2005), with the highest streamflow variability occurring in the spring (Maurer and Lettenmaier 2004). An estimated onequarter to one-third of total MRB flow, as measured at the U.S. Geological Survey (USGS) Hermann, Missouri, gauge (06934500), is generated by the upper basin, leaving the lower basin as the primary source of flood generation (Norton et al. 2014; Qiao et al. 2014).

Synoptic-scale climate drivers of MRB streamflow, including the streamflow variability's connection to sea surface temperatures (SST) and ocean-atmosphere oscillations such as the El Niño-Southern Oscillation (ENSO) system in the tropical Pacific, have not yet been clearly identified. There are some indications that northern Pacific conditions, such as those described by the Pacific-North American (PNA) pattern, might be important for long-term variability in flow and winter snowpack in the MRB (Najibi et al. 2017; Pederson et al. 2013). However, other studies have found that circulation patterns summarized by indices measuring Pacific and Atlantic Ocean conditions, including the Southern Oscillation index (SOI) and the North Atlantic Oscillation (NAO), do not explain much variation in MRB streamflow or improve streamflow models (Olsen et al. 1999; Maurer and Lettenmaier 2004) and that SSTs are not associated with streamflow in either a simultaneous or precursor capacity (Hoerling et al. 2014).

The challenges of managing a water resource subject to both extreme droughts and floods under natural variability, with the added uncertainty of climate change impacts, are a concern to water users in the basin. Before being able to assess the drivers of extreme events in the MRB and the potential impacts of future climate change, a thorough assessment of the fundamental hydroclimatology of the basin is needed. In this study, we use observed and modeled hydroclimatic data and estimated natural flow records to build on previous work and address these research questions: What are the major source regions for total water-year streamflow in the Missouri River, what climate parameters are important for streamflow in the upper and lower portions of the MRB, and what trends are evident in climate and streamflow through the instrumental period?

Following a description of the data used in this study in section 2, we provide an overview of the hydrogeography of the basin in section 3, describing the watersheds with the most important contributions to annual streamflow in the MRB. We then discuss the key climatic controls on flows in section 4, with a focus on two major source regions, one in the upper MRB and one in the lower MRB. Within this section, we investigate large-scale ocean-atmosphere drivers of hydroclimate in the MRB and trends in climate variables that influence streamflow. We use section 5 to synthesize key points of this study and the implications for future MRB hydroclimate.

\section{Data}

Estimates of naturalized flow for the upper and lower MRB were obtained from the Bureau of Reclamation, the State of Montana Department of Water Resources, the USGS, and the U.S. Army Corps of Engineers (Table 1). These gauge data have had the effects of dams, diversions, and depletions from irrigation removed from the flow record by the respective agencies/ investigators and represent best estimates of natural flow in the river (see original cited studies in Table 1 for dataset limitations and specific methods). Water-year (October-September) values are given as average flow in cubic meters per second. The main gauges used in this study (Missouri River at Ft. Benton and Yellowstone River at Sidney in the upper MRB, and Missouri River at Hermann in the lower MRB; Fig. 1) cover the years 1912-2011. Additionally, we use the sum of three streamflow records to estimate total streamflow for the upper Missouri River main stem (total streamflow above the confluence with the Yellowstone River). The three gauges used for the sum are the Missouri River at Landusky, the Musselshell at Mosby, and the Milk River at Nashua. The period of record used for the Missouri River main stem is limited by the Milk River record, which begins in 1941, and the Musselshell River record, which ends in 2010, limiting the upper Missouri River main stem estimate to the years 1941-2010. The Missouri River at Ft. Benton gauge, which is correlated with the sum of the flows at the three gauges with a Pearson correlation coefficient $r$ of 0.95 , is used as a proxy for the Missouri main stem flow in some analyses. 
TABLE 1. Datasets used in this study.

\begin{tabular}{|c|c|c|c|}
\hline Data description & Units & Years & Source \\
\hline 500-hPa geopotential heights & $\mathrm{m}$ and $z$ scores & $1912-2011$ & $20 \mathrm{CR} 2^{\mathrm{a}}$ \\
\hline $\begin{array}{l}\text { PRISM monthly temperature and } \\
\text { precipitation data }\end{array}$ & ${ }^{\circ} \mathrm{C}$ and $\mathrm{mm}$ & $1912-2011$ & PRISM monthly climate data ${ }^{\mathrm{b}}$ \\
\hline $\begin{array}{l}\text { Bighorn River near St. Xavier, MT (USGS } \\
\text { gauge } 6287000 \text { ), estimated } \\
\text { natural flow }\end{array}$ & $\mathrm{m}^{3} \mathrm{~s}^{-1}$ & 1936-2011 & Bureau of Reclamation \\
\hline $\begin{array}{l}\text { Milk River at Nashua, MT (USGS gauge } \\
6174500 \text { ), modeled natural flow }\end{array}$ & $\mathrm{m}^{3} \mathrm{~s}^{-1}$ & $1941-2011$ & Bureau of Reclamation \\
\hline $\begin{array}{l}\text { Missouri River at Fort Benton, MT (USGS } \\
\text { gauge 6090800), estimated } \\
\text { natural flow }\end{array}$ & $\mathrm{m}^{3} \mathrm{~s}^{-1}$ & $1912-2011$ & Cary and Parrett (1996) \\
\hline $\begin{array}{l}\text { Missouri River near Landusky, MT (USGS } \\
\text { gauge } 6115200 \text { ), estimated } \\
\text { natural flow }\end{array}$ & $\mathrm{m}^{3} \mathrm{~s}^{-1}$ & 1928-2011 & Cary and Parrett (1996) \\
\hline $\begin{array}{l}\text { Missouri River at Toston, MT (USGS gauge } \\
6054500 \text { ), estimated natural flow }\end{array}$ & $\mathrm{m}^{3} \mathrm{~s}^{-1}$ & 1929-2011 & Bureau of Reclamation \\
\hline $\begin{array}{l}\text { Musselshell River at Mosby, MT (USGS } \\
\text { gauge 6130500), estimated natural flow }\end{array}$ & $\mathrm{m}^{3} \mathrm{~s}^{-1}$ & 1930-2010 & State of Montana \\
\hline $\begin{array}{l}\text { Yellowstone River at Corwin Springs, MT } \\
\text { (USGS gauge 6191500), estimated } \\
\text { unregulated flow }\end{array}$ & $\mathrm{m}^{3} \mathrm{~s}^{-1}$ & $1912-2002$ & USGS; Chase (2014) \\
\hline $\begin{array}{l}\text { Yellowstone River near Sidney, MT (USGS } \\
\text { gauge 6329500), estimated } \\
\text { unregulated flow }\end{array}$ & $\mathrm{m}^{3} \mathrm{~s}^{-1}$ & $1912-2011$ & USGS; Chase (2014) \\
\hline $\begin{array}{l}\text { Missouri River at Hermann, MO (USGS } \\
\text { gauge 6934500), estimated natural flow }\end{array}$ & $\mathrm{m}^{3} \mathrm{~s}^{-1}$ & $1912-2011$ & Army Corps of Engineers \\
\hline $\begin{array}{l}\text { Missouri Headwaters basin (HUC 100200) } \\
1 \text { April SWE }\end{array}$ & $z$ scores & 1936-2011 & NRCS/Pederson et al. (2011a) ${ }^{c}$ \\
\hline $\begin{array}{l}\text { Upper Yellowstone basin (HUC 100700) } \\
1 \text { April SWE }\end{array}$ & $z$ scores & 1936-2011 & NRCS/Pederson et al. (2011a) ${ }^{c}$ \\
\hline Bighorn basin (HUC 100800) 1 April SWE & $z$ scores & 1936-2011 & NRCS/Pederson et al. $(2011 a)^{c}$ \\
\hline Missouri basin (HUC 10) 1 April SWE & $z$ scores & $1936-2011$ & NRCS/Pederson et al. $(2011 a)^{c}$ \\
\hline Sea surface temperatures & ${ }^{\circ} \mathrm{C}$ & $1912-2010$ & NOAA Extended Reconstructed SST V3b $\mathrm{b}^{\mathrm{a}}$ \\
\hline
\end{tabular}

${ }^{a}$ https://www.esrl.noaa.gov/psd/data

${ }^{\mathrm{b}} \mathrm{http}: / /$ www.prism.oregonstate.edu/

${ }^{\mathrm{c}}$ NRCS raw data archive: https://www.wcc.nrcs.usda.gov/snow/. Original Pederson et al. (2011a) basin 1 April SWE summaries: https:// www.ncdc.noaa.gov/paleo-search/study/11205. Records added and updated for this study.

For climate analyses, we use monthly temperature and precipitation data for water years 1912-2011 from the Parameter-Elevation Regressions on Independent Slopes Model (PRISM) dataset (Daly et al. 2008) on a $4 \mathrm{~km} \times$ $4 \mathrm{~km}$ grid. The gridded monthly temperature and precipitation data were aggregated at several different basin scales [based on USGS Hydrologic Units (HU), described in the sections that follow]. While there is concern about the potential for biases in PRISM temperatures, particularly in nighttime minimums across higher elevations (Oyler et al. 2015a), little difference exists between average monthly temperature estimates from PRISM and the inhomogeneity-adjusted Topography Weather (TopoWX) gridded dataset (Oyler et al. 2015b). Specifically, bias correction in TopoWX tended to warm monthly maximum and cool monthly minimum temperature values, resulting in negligible changes to the calculated monthly average temperature estimates derived from these values when compared against PRISM data. Since the monthly water balance model used in this study is driven by average monthly temperature values, and the majority of the MRB is dominated by the mid- to low elevations, the potential for bias in model output and results due to artificially high minimum temperature estimates over recent decades is considered minimal. For large-scale atmospheric circulation analyses, we obtained seasonally gridded $\left(2^{\circ} \times 2^{\circ}\right)$ Northern Hemisphere geopotential heights (GPHs) from version 2 of the Twentieth Century Reanalysis (20CR2; Compo et al. 2011) and SSTs from NOAA Extended Reconstructed SST version $3 b$ (Smith et al 2008). We calculated GPH anomalies ( $z$ scores) for $1912-2011$ over $18^{\circ}-70^{\circ} \mathrm{N}$ latitude and $170^{\circ} \mathrm{E}-$ $40^{\circ} \mathrm{W}$ longitude using the monthly $500-\mathrm{hPa}$ GPH data.

For snowpack data, we used observed 1 April snow water equivalent (SWE) to reflect the most common 
date of maximum snow accumulation. The 1 April SWE estimates were based on observed SNOTEL and snow course records obtained from the Natural Resource Conservation Service (NRCS; https://www.wcc.nrcs. usda.gov/snow/) and summarized at the USGS HU6 scale using only records with 20 or more years of continuous observations (methods described in Pederson et al. 2011a). The resulting HU6 observational SWE records span the years 1936-2016 and were averaged across the major headwaters contributing areas. The "Missouri Headwaters" basinwide SWE estimate was generated from the Milk/St. Mary, Marias, Upper Missouri, Ft. Peck Lake, and Missouri Headwaters subbasins (HUs 100500, 100302, 100301, 100401, 100402, and 100200). The "Yellowstone Headwaters" SWE estimate included the Upper Yellowstone, Bighorn, and the Tongue/Powder subbasins (HUs 100700, 100800, and 1009). Finally, the entire "Missouri Basin Headwaters" 1 April SWE estimate includes the subbasins from the Missouri and Yellowstone Headwaters (above) and the North and South Platte subbasins (HUs 101900 and 101800). The Missouri and Yellowstone Headwaters 1 April SWE estimates are primarily representative of MRB subregion 1 (Fig. 1). Snow fraction, generated from the monthly water balance (see section $3 b$ ), is computed as October-March total snowfall divided by total precipitation.

\section{Hydrogeography of the Missouri River basin}

For this paper, the division between the upper and lower Missouri River basins (UMRB and LMRB, respectively) is defined as the confluence between the Missouri River main stem and the Yellowstone River in far western North Dakota (Fig. 1). The UMRB is further divided into the Missouri River main stem and Yellowstone River drainages, with the Yellowstone River contributing slightly more to upper-basin flows than the main stem (Table 2). A relatively large proportion (considering the size and area of the basin) of UMRB flows are generated in the high headwaters. In the main stem basin, flows measured at the gauge at Toston (USGS gauge 06054500), which drains the headwaters of the Missouri River, account for nearly half of the main stem flow. In the Yellowstone basin, flows at the Yellowstone at Corwin Springs and Bighorn at St. Xavier headwaters gauges account for over half of the Yellowstone River flow. Together, these three headwaters gauges contribute about $51 \%$ of the entire UMRB flow.

The UMRB flows (the sum of the Missouri main stem and Yellowstone River basin flows) account for approximately $28 \%$ of the total flow at the mouth of the Missouri River (Table 2). This is in close agreement with the value reported by Norton et al. (2014) of $25 \%$ for the UMRB (for 1960-2011). In contrast to snowmeltdominated watersheds of the western United States, where high-elevation headwaters typically account for most of the basin flow, the largest contribution to total flows of the MRB comes from the part of the basin closest to the mouth, with nearly half $(44 \%)$ of the annual streamflow originating in the part of the lower basin that includes the Nishnabotna, Grande, Blackwater, and Osage River drainages (Norton et al. 2014). The four intervening subbasins each contribute between $4 \%$ and $10 \%$ each to the total annual MRB flow (Norton et al. 2014).

\section{a. Missouri River subregions}

To examine in more detail the source regions for MRB flow and the climatic factors that influence flow, we used a correlation-based classification approach to divide the basin into subregions that share similar characteristics of precipitation variability. Monthly precipitation data from PRISM for water years 19122011 were aggregated for each of the 311 HU8 regions in the MRB (Fig. S1 in the online supplemental material). Data were converted to $z$ scores of monthly precipitation and then classified into subregions using the follow process. First, the time series at each HU8 is correlated with the time series for all other HU8s at a monthly time scale. The HU8 that is correlated with the most other HU8s (at $r \geq 0.5, p<0.001$ ) is removed from the original set of HU8s along with all of the HU8s that are significantly correlated with the selected HU8; these HU8s comprise the first group. The process is repeated with the remaining HU8s to obtain the second and then subsequent groups. After assigning as many HU8s as possible to groups, six groups were identified with at least 10 HU8s assigned to each group. The initial classification process resulted in a total of 297 (over 95\%) of the 311 HU8s being assigned to one of the six groups. To ensure that all HU8s were assigned to the optimal group and to assign all 311 of the HU8s to a group, monthly precipitation for the HU8s in each group were averaged to produce a subregion average. Each individual HU8 precipitation series was then correlated with each subregion series to confirm membership in the appropriate subregion group. The median correlations between each HU8 with the respective average group time series ranged from 0.76 (group 1) to 0.83 (group 6). Subregions are shown in Fig. 1.

\section{b. Key source regions}

A water balance model was used to identify the most important subregions described above with respect to contributions to total basin flow. We employed a model that uses an accounting procedure to compute the 
TABLE 2. Contributions of UMRB streamflow to Missouri River streamflow at its mouth (Hermann, MO), Missouri River main stem and Yellowstone River near its mouth (Sidney, MT) to UMRB flow, and headwaters flows to the main stem and Yellowstone River basin flows, for the common period 1941-2010 (Yellowstone at Corwin Springs to 2002).

\begin{tabular}{|c|c|c|}
\hline Gauge & Average monthly flow $\left(\mathrm{m}^{3} \mathrm{~s}^{-1}\right)$ & Percent of flow \\
\hline \multirow{2}{*}{$\begin{array}{l}\text { Upper Missouri River (Yellowstone and } \\
\text { Missouri main stem) }\end{array}$} & 803.4 & $\%$ of total Missouri River: $28.1 \%$ \\
\hline & & $\%$ of UMRB flow: \\
\hline Missouri main stem ${ }^{\mathrm{a}}$ & 372.4 & $46.4 \%$ \\
\hline \multirow[t]{2}{*}{ Yellowstone River at Sidney, MT } & 431.0 & $53.6 \%$ \\
\hline & & $\%$ of Missouri River main stem flow: \\
\hline Missouri River at Toston MT & 179.6 & $48.2 \%$ \\
\hline \multirow[t]{2}{*}{ Missouri River at Fort Benton, MT } & 275.1 & $73.9 \%$ \\
\hline & & $\%$ of Yellowstone River at Sidney flow: \\
\hline Yellowstone River at Corwin Springs, MT & 89.8 & $20.8 \%$ \\
\hline Bighorn River at St. Xavier, MT & 137.7 & $31.9 \%$ \\
\hline Missouri River at Hermann, MO & 2862.6 & \\
\hline
\end{tabular}

${ }^{\text {a }}$ Sum of flows from Missouri River at Landusky, MT; Musselshell River at Mosby, MT; and Milk River at Nashua, MT; the equivalent of the Missouri River flow before the confluence with the Yellowstone River

allocation of water among various components of the hydrologic system, including climatic water supply and demand, seasonality in climatic water supply and demand, snow accumulation and melt, and soil moisture storage (McCabe and Wolock 2011a,b). Monthly PRISM temperature and precipitation data for the HU8s within each subregion were used as inputs to a monthly time step water balance model. The water balance model computes monthly potential evapotranspiration, soil moisture storage, actual evapotranspiration, snow accumulation and melt, and runoff.

Water balance model parameters used for this study were taken from parameter sets developed in previous studies (McCabe and Wolock 2011a,b). Soil moisture storage capacity for each HU8 was computed using the available water-capacity values from the State Soil Geographic (STATSGO) database by assuming a 1-m rooting depth (U.S. Department of Agriculture 1994). The water balance model has been assessed and verified in several previous studies (McCabe and Wolock 2008; Gray and McCabe 2010; McCabe and Wolock 2011a,b). Although there are some biases in water balance model runoff estimates (attributed to hydrologic processes not included in the water balance model, such as the effects of groundwater contributions on runoff), strong temporal correlations between water balance model estimated and measured runoff suggest that the water balance model reliably simulates variability in runoff response to temporal variability in temperature and precipitation (McCabe and Wolock 2011b). Additional details regarding the water balance model and model evaluation are described in McCabe and Wolock (2011a,b).

For each subregion, long-term (water years 19122011) mean monthly potential evapotranspiration, actual evapotranspiration, and runoff were computed from the water balance model output for the 311 HU8s (Fig. S1) and then averaged for the region (Fig. 2). For four of the subregions $(2,3,4$, and 5), potential evapotranspiration is nearly equal to or greater than precipitation for almost all months, which results in little runoff produced in these subregions (Figs. 2b-e). For subregions 1 and 6 , precipitation exceeds potential evapotranspiration for October-March, which results in runoff (Figs. 2a,f). Thus, most of the runoff in the MRB is generated in subregion 1 , the high headwaters of the MRB, and subregion 6 , the part of the basin located immediately upstream of the mouth. This finding is supported by Fig. 3, which illustrates a comparison of monthly runoff from each subregion (Fig. 3a) and the corresponding contribution of subregion runoff to total MRB runoff (Fig. 3b). During the cool-season months, the largest percentage of runoff in the MRB is generated by subregion 6 , whereas during the warm-season months, runoff is generated primarily by subregions 1 and 6 , with runoff from subregion 1 contributing slightly more than subregion 6 in this season (Fig. 3b). For the regional climate analyses in this study, the UMRB is the average of subregions 1 and 2 (Fig. 1) to be compatible with the full region that drains the Missouri main stem and Yellowstone Rivers, and we refer to subregion 6 as the LMRB climate subregion, acknowledging that these regions do not encompass the full upper and lower basins.

\section{Climatic controls on Missouri River flow}

As described above, the UMRB (subregions 1 and 2) and the part of the LMRB just upstream of the mouth (subregion 6) are the two most important parts of the MRB in terms of contributions to total basin flow ( $\sim 72 \%$ for the water year, but varies seasonally). 

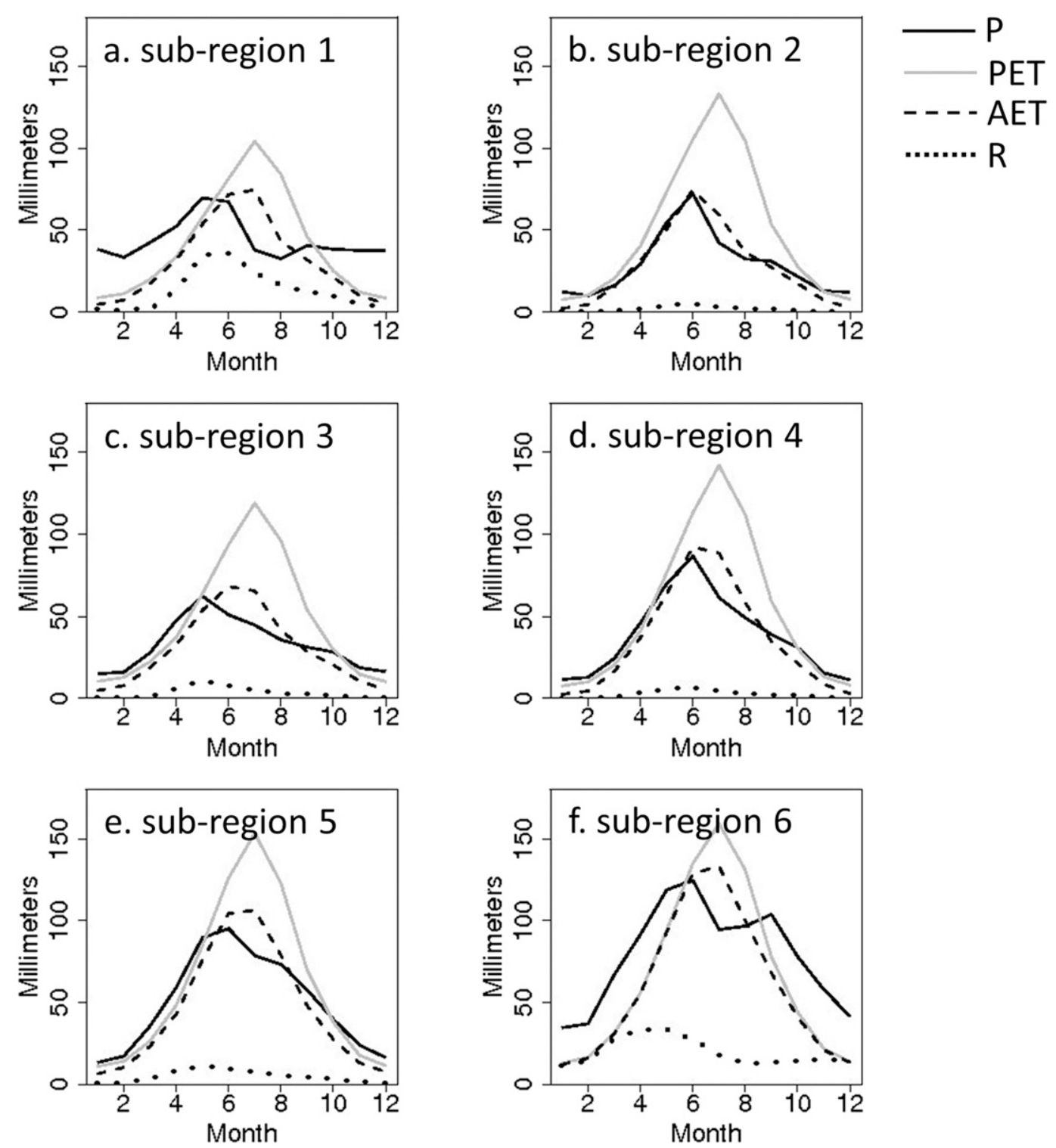

FIG. 2. Mean monthly precipitation $P$, PET, actual evapotranspiration (AET), and runoff $R$ for the six subregions identified for the MRB. Subregions shown in Fig. 1.

Because these two regions are in climatically different parts of the basin, we first investigate their basic climate characteristics and then discuss the climatic factors related to streamflow in these two parts of the basin. Using subregion mean climate time series, we created box plots of monthly temperature and precipitation for the UMRB (subregions 1 and 2) and LMRB (subregion 6) (Fig. 4). Patterns of monthly precipitation are similar between the upper and lower basins, but overall precipitation amounts are significantly higher in the LMRB, as is the variability between years, particularly in the summer and fall. The UMRB and the LMRB also display very similar monthly temperature patterns, but with lower median temperatures in the UMRB each month (Fig. 4).
To assess the seasonal impacts of monthly temperature and precipitation on overall water-year flow, we examined Pearson correlation coefficients $r$ for the primary variable (precipitation) and partial correlations for the secondary variable (temperature) with total wateryear streamflow. Partial correlations were used to remove the influence of precipitation from the evaluation of the influence of temperature on observed streamflow. These analyses were conducted separately for UMRB and LMRB flows, where UMRB flow is the summation of the Yellowstone at Sidney and Missouri at Ft. Benton gauges and LMRB flow is based on the Missouri River at the Hermann, Missouri, gauge. LMRB flow thus integrates the effects of climate on flow throughout the 

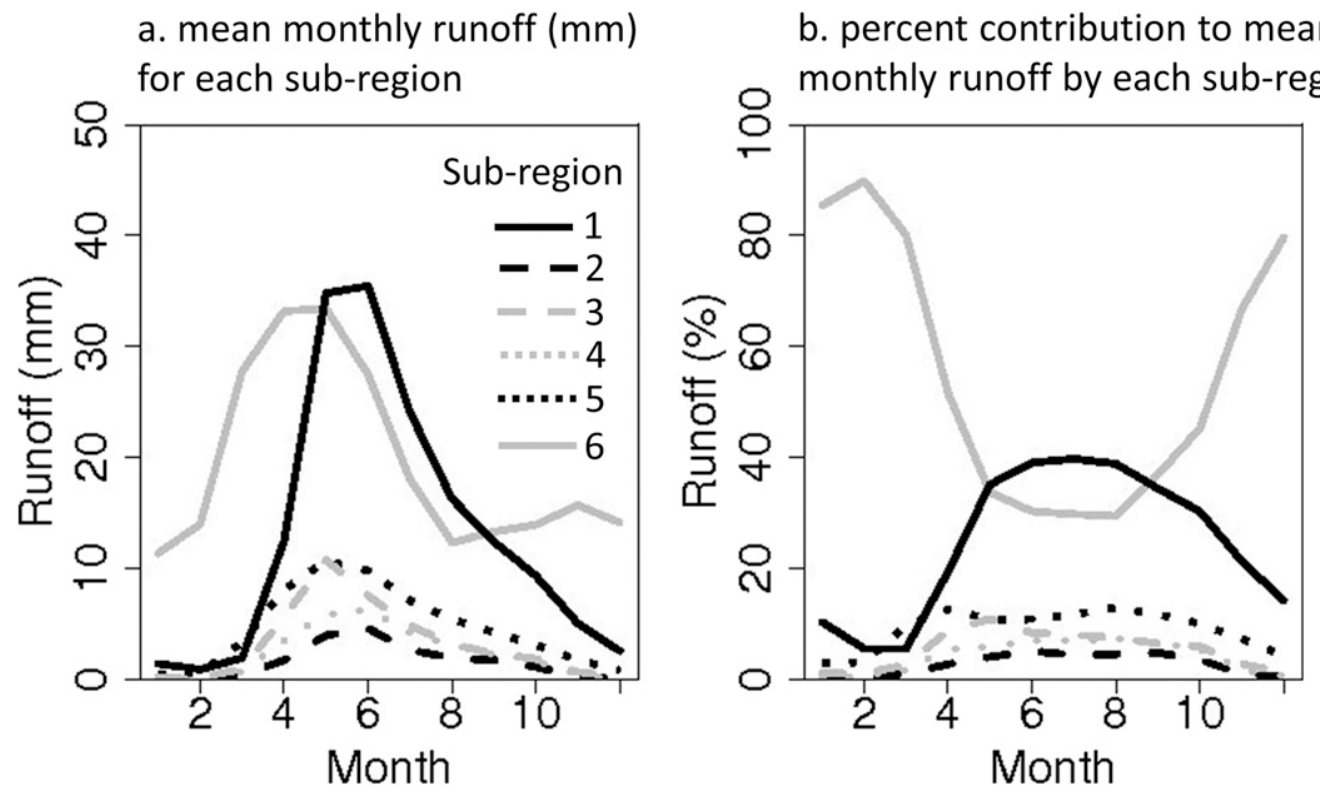

FIG. 3. (a) Mean monthly runoff for each subregion identified for the MRB, and (b) percent contribution to total mean monthly Missouri River runoff from each subregion. Subregions shown in Fig. 1.

basin and reflects total MRB flows. However, as discussed above, the UMRB flows account for a smaller portion of total water-year flows $(<30 \%)$, so the dominant climate influences are related to the LMRB subregion highlighted here. The seasonal connections between precipitation, temperature, and streamflow are quite different between the UMRB and the LMRB (Fig. 5). Following expected patterns for a snow-dominated region, the UMRB flow is most strongly correlated with winter precipitation, while spring through early summer temperatures and spring precipitation are additional important components of the total water-year flow. In contrast, in the LMRB, streamflow is significantly correlated with precipitation in almost every month of the year (Fig. 5), with a peak in the late spring and early summer. Monthly temperature correlations for the LMRB are also different from those for the UMRB: after removing the precipitation signal, temperature retains a strong correlation with LMRB streamflow in December and in the summer and early fall (Fig. 5).

Because of the importance of cool season precipitation in the UMRB, we further examined the role of 1 April SWE using simple stepwise regression models to identify the contribution of SWE versus other climatic variables important for water-year streamflow. We used streamflow at key headwaters gauges in the UMRB (the Missouri at Toston, Yellowstone at Corwin Springs, and Bighorn at St. Xavier) as the predictands. The pool of candidate predictors for each gauge included temperature and precipitation for all months that correlated significantly $(p<0.05)$ with water-year flow. Observed 1 April SWE and several sets of temperature or precipitation data averaged or totaled for consecutive months were also included in the pool. Climate data (i.e., monthly temperature and precipitation) used for each gauge were averaged from data for the PRISM grid cells within each basin (Missouri Headwaters, Upper Yellowstone, and Bighorn). Common years of analysis were 1936-2002. Results of the stepwise regression analysis indicate the important contribution of winter snowpack in the Missouri River headwaters gauge at Toston and in the Yellowstone headwaters gauge at Corwin Springs. The 1 April SWE explains 50\%-64\% of the variance in water-year flow at these gauges (Fig. 6). In the Bighorn River basin, winter precipitation is also a key predictor of flow, but it is the first half of the winter season (October-January) that is most important, while 1 April SWE accounts for only $5 \%$ of the variability in flow. In this basin, a relatively large proportion of the variance in flow is explained by spring precipitation. This may be due to its location farther to the east than the other two gauges, allowing a stronger influence of the springtime moisture influx from the Gulf of Mexico.

\section{a. Large-scale circulation associated with MRB hydroclimate}

For a more complete understanding of the climatic controls on streamflow in the MRB, we investigated the large-scale climatic features that influence the regional climatology. First, we examined potential synoptic-scale 
UMRB
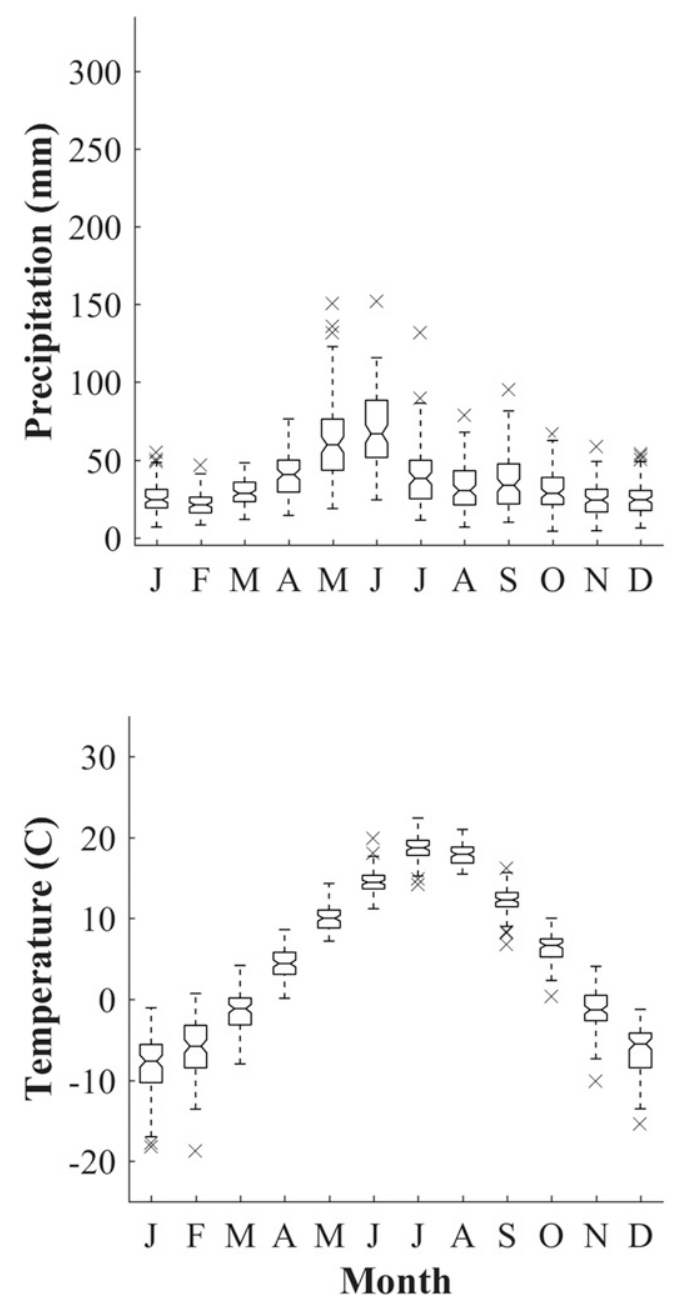

LMRB
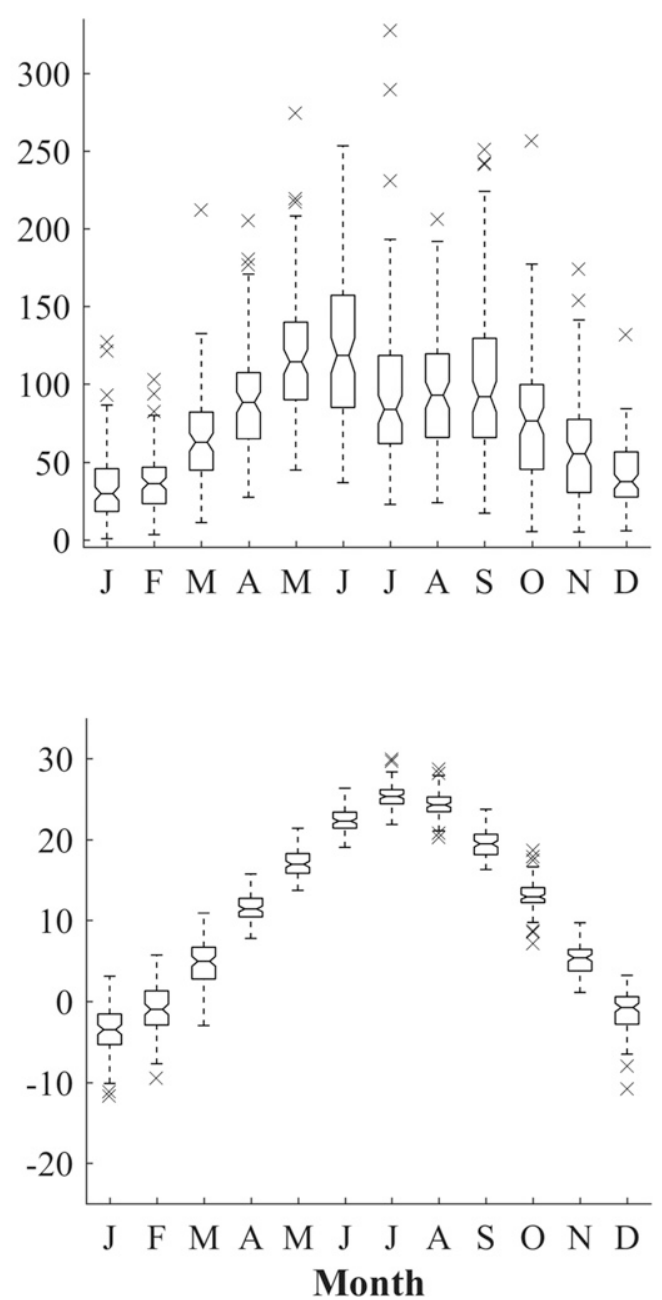

FIG. 4. Monthly distributions of (top) precipitation and (bottom) temperature in the (left) UMRB and (right) LMRB for water years 1912-2011. The top and bottom of each box indicates the 25th and 75th percentiles, respectively; horizontal lines indicate the median values. Outliers (monthly averages more than 1.5 times the interquartile range from the top or bottom of the box) are shown with exes.

drivers through spatial field correlations between wateryear streamflow and Northern Hemisphere GPH and SSTs. Based on the climatically important seasons identified in Fig. 5, we assessed GPH and SST correlation fields over the 4-month period of October-January for UMRB flow, and we used the April-July period for LMRB flow. In the UMRB, positive correlations between GPH and streamflow are seen over the Aleutian Islands, Mexico, and the eastern United States, along with negative correlations over northwestern North America (Fig. 7). This pressure pattern is similar to one previously identified as the main mode of variability for western U.S. streamflow (including the Missouri River headwaters) in winter (Malevich and Woodhouse 2017). It is characteristic of the PNA, which indicates whether circulation across the United States is zonal or meridional (Wallace and Gutzler 1981), with an enhanced Pacific jet and meridional flow in the positive phase and more zonal flow across North America in the negative phase (Henderson and Robinson 1994). The SST patterns show a positive correlation between UMRB flow and SSTs in the central North Pacific and negative correlations elsewhere, particularly the west coast of North American and in the central North Atlantic (Fig. 7). The Pacific pattern indicates an ENSO-like response, with warm SSTs near the equator and the west coast of the United States corresponding to low flows in the UMRB, and vice versa for high flows. This is consistent with the hydroclimate response to ENSO in the northwestern United States (Wise 2010) and with previously noted 

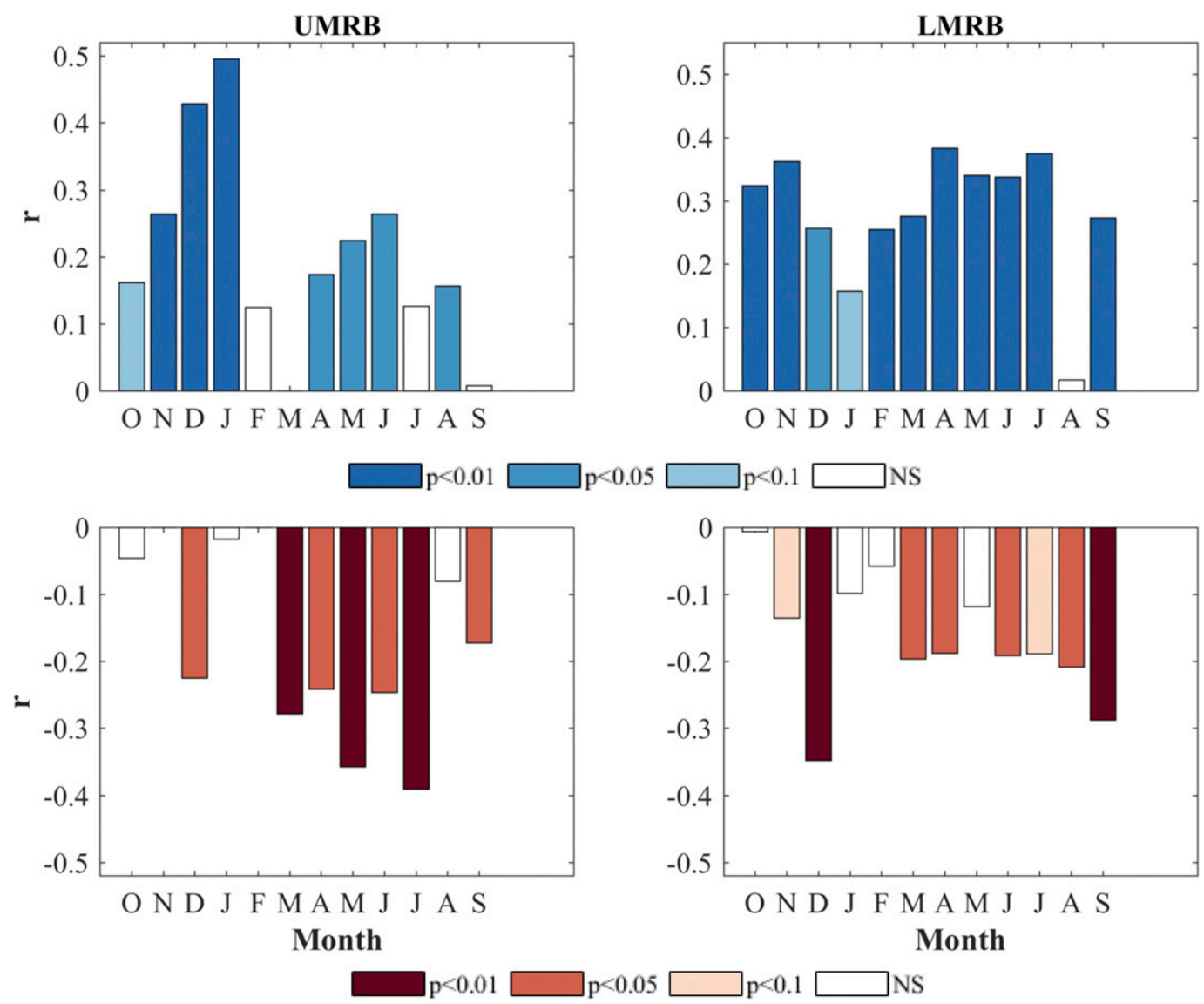

FIG. 5. (top) Correlations $r$ between precipitation in each month of the water year and total water-year streamflow and (bottom) partial correlations between temperature and total water-year streamflow in the (left) UMRB and (right) LMRB. Bar color denotes significance level.

correlations between La Niña and high runoff in the UMRB (Hoerling et al. 2013). The strong negative correlations with Atlantic SSTs (low flows in the UMRB associated with warm Atlantic SSTs) are suggestive of the influence of the Atlantic multidecadal oscillation (AMO). The AMO is a measure of Atlantic SSTs (Enfield et al. 2001). Much of the United States experienced below-normal precipitation during the positive AMO phase (warm North Atlantic Ocean) in the twentieth century (Enfield et al. 2001; McCabe et al. 2004), likely through SST-induced changes in pressure anomalies and associated circulation patterns affecting the North American continent (Hu et al. 2011).

The spatial correlation fields for LMRB flow (Fig. 7) are quite different from those for the UMRB, representing both a different season of analysis and different climatic controls, but with several important similarities. Like the UMRB, there are strong, negative correlations between atmospheric pressure over North America and streamflow in the LMRB. The strongest correlations are shifted to the southeast in the LMRB relative to the
UMRB and stretch across the central conterminous United States. This pressure pattern makes intuitive sense, with low flows corresponding to high pressure and associated subsidence and warming over the central United States and high flows associated with low pressure instability over this part of the continent in spring and summer. Also like the UMRB, there are negative correlations between LMRB streamflow and SSTs along the west coast of North America and in the North Atlantic, which may represent similar climate influences despite the different season. Unlike many Northern Hemisphere ocean-atmosphere oscillations, the AMO exerts a strong impact on summer precipitation in North America (Enfield et al. 2001; Hu et al. 2011). The cool phase of the AMO is associated with enhanced high pressure over the Atlantic Ocean, southerly flow from the Gulf of Mexico into the central United States, and more frequent summer storms (Hu et al. 2011). One of the major differences between the spatial correlation fields in the UMRB and LMRB occurs in the North Pacific. Unlike the UMRB, the LMRB is negatively 

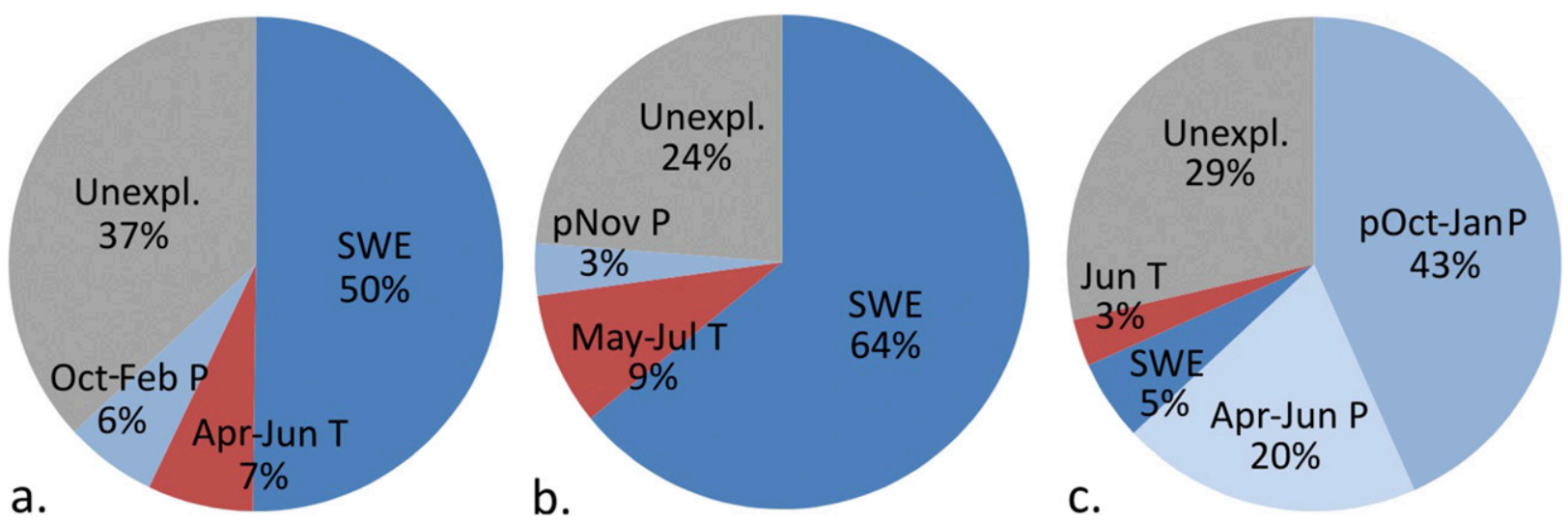

FIG. 6. Major climatic factors influencing water-year streamflow variability at three headwaters gauges: (a) Missouri River at Toston, (b) Yellowstone River at Corwin Springs, and (c) Bighorn River at St. Xavier. Values are percent of total variance explained. Climatic variables are October-February total precipitation (Oct-Feb P), April-June mean temperature (Apr-Jun T), 1 April SWE, May-July mean temperature (May-Jul T), November precipitation (pNov $P$ ), June temperature (Jun $T$ ), April-June total precipitation (Apr-Jun $P$ ), and October-January total precipitation (pOct-Jan $P$ ).

correlated with the Aleutian pressure center and with central North Pacific SSTs. These dissimilarities may reflect important differences in climatic controls: while the UMRB correlation fields indicate the North Pacific-focused, wintertime PNA, the LMRB patterns most closely resemble the Atlantic-focused, summertime influences of AMO and NAO. The NAO, which represents changes in Icelandic low and Azores high pressure centers over the North Atlantic (Hurrell 1995; Jones et al. 1997), is one of the few atmospheric teleconnection patterns present through all seasons of the year (Barnston and Livezey 1987). The NAO has been shown to impact summer streamflow in North America (Coleman and Budikova 2013), as well as summer Great Plains hydroclimate variability (RuizBarradas and Nigam 2005), through its influence on inplace strengthening of the Great Plains low-level jet bringing moisture from the Gulf of Mexico (Weaver and Nigam 2008).

To further examine atmospheric patterns associated with high and low flows, we used 500-hPa GPH anomalies along with high- and low-flow streamflow years in the UMRB and LMRB, defined as water years with a \pm 0.5 standard deviation from mean water-year flow. This categorization resulted in 30-38 years in each highand low-flow subset for the UMRB and LMRB. UMRB flow is the summation of the Missouri River at Ft. Benton and Yellowstone River at Sidney gauges and was compared to mean 500-hPa GPH height anomalies for October-January, while LMRB flow was based on the Missouri River at Hermann gauge and compared to mean 500-hPa GPH anomalies for April-July. We used the self-organizing maps (SOM) technique to organize the GPH anomaly dataset into a two-dimensional grid topology of statistically distinguishable patterns, or "nodes." SOM is a type of unsupervised, artificial neural network approach that produces archetypal nodes that span the continuum of data, with more nodes in areas of high data density (Hewitson and Crane 2002). The SOM technique requires the user to make an a priori decision concerning the number of nodes $K$, with a trade-off between being able to completely represent the variability in the data (more nodes) and being able to discern meaningful patterns in the data (less nodes). Here we use the false discovery rate technique (Wilks 2006; Johnson 2013) to determine the value of $K+1$, or the point at which one or more pairs of SOM node patterns become statistically indistinguishable at the $95 \%$ confidence level for each data subset. We then use the SOM Toolbox (http://www.cis.hut.fi/somtoolbox) to create a $K$-node SOM, which "self-organizes" into a twodimensional grid topology. Each input value presented to the SOM (in this case, GPH anomalies from 1912 to 2011) is assigned to the best-matching node based on Euclidean distance.

The resulting SOMs (Figs. 8, 9) show the synoptic patterns associated with high- and low-flow streamflow years in the UMRB and LMRB during the seasons that are most important for precipitation in each region (October-January and April-July, respectively). Although high-flow years in both the UMRB and LMRB were associated with large, low pressure troughs across North America, the axes of these troughs and other pressure features were quite different. In the UMRB, a weak Aleutian low and a trough that stretches from north to south across central North America directs frontal storms across the region during high-flow years (Fig. 8a). The four nodes of Fig. 8a are distinct in terms 
UMRB - ONDJ GPH

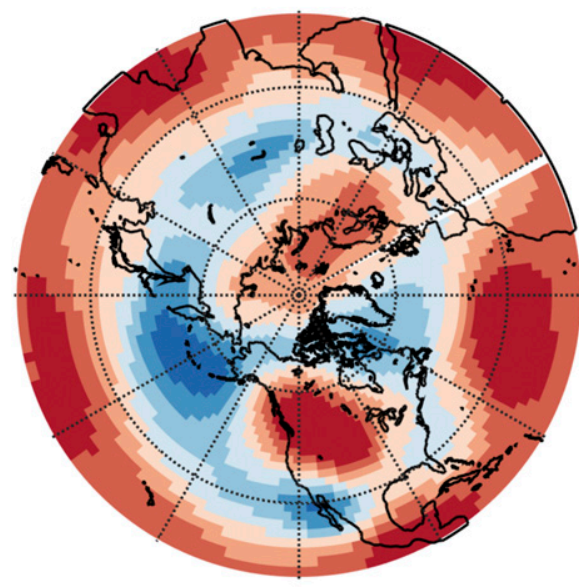

UMRB - ONDJ SSTS

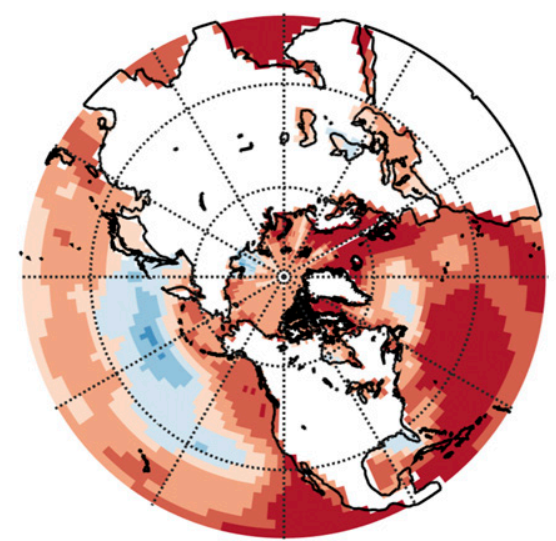

LMRB - AMJJ GPH

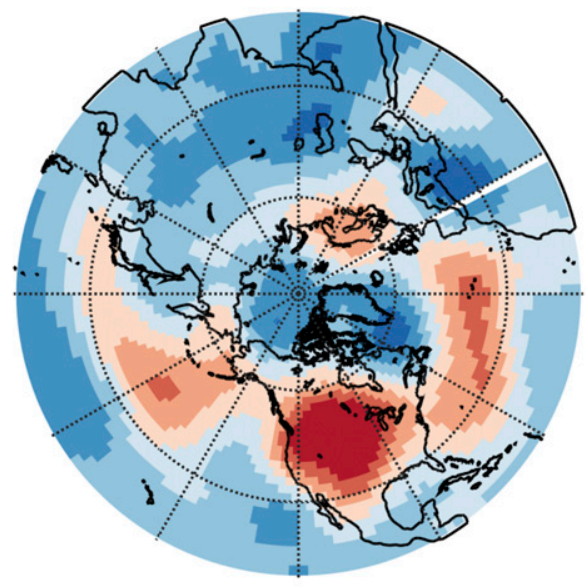

LMRB - AMJJ SSTs

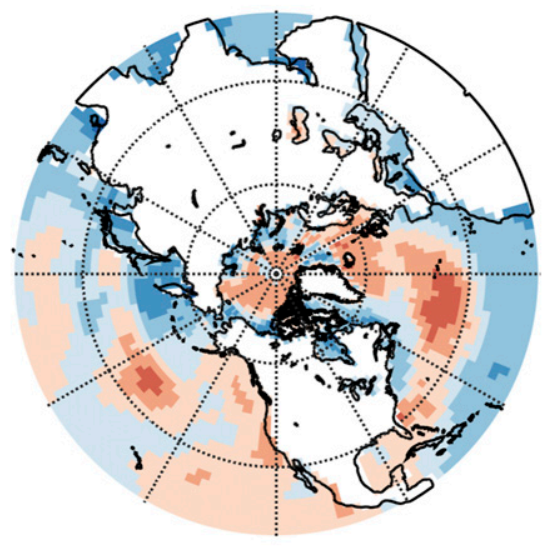

0.4
0.3

0.2

0.1

$-0$

$-0.1$

$-0.2$

$-0.3$

$-0.4$

FIG. 7. Correlations between water-year streamflow and (top) 500-hPa GPHs and (bottom) SSTs. (left) OctoberJanuary GPHs and SSTs used for correlation with UMRB streamflow and (right) April-July GPH and SSTs used for correlation with LMRB streamflow.

of the strength and placement of the low pressure trough and whether the Pacific pattern is dominated by a very weak Aleutian low (as in node 3), by a high pressure cell off northern Mexico (node 2), or both (node 4). These patterns, particularly node 3 , resemble those seen in positive North Pacific index (NPI) years (Trenberth and Hurrell 1994). The NPI is a measure of the strength of the Aleutian low, and positive NPI indicates a weak Aleutian low and troughing over western Canada and the northwestern United States, leading to enhanced winter precipitation. In the LMRB high-flow years, there is a large, strong low pressure trough oriented diagonally from southern California through eastern Canada in each of the four nodes, with differences in the positioning of the trough axis (Fig. 8b). These patterns suggest spring and summertime instability, uplift, and convection across much of the MRB.

Low flow in the UMRB was consistently associated with ridging over western Canada and the U.S. Pacific Northwest, a strong Aleutian low, and low pressure over Baja Mexico (Fig. 9a). Each of the four nodes displays variations in the placement and strength of those features. Nodes 1 and 3 are characteristic of a positive PNA or El Niño-type conditions. Nodes 2 and 4 are characteristic of a Rex block (Rex 1950), where north-to-south circulation around a high pressure anomaly located to the north of a low pressure anomaly results in weak eastward progression of weather systems and stagnant 
a)
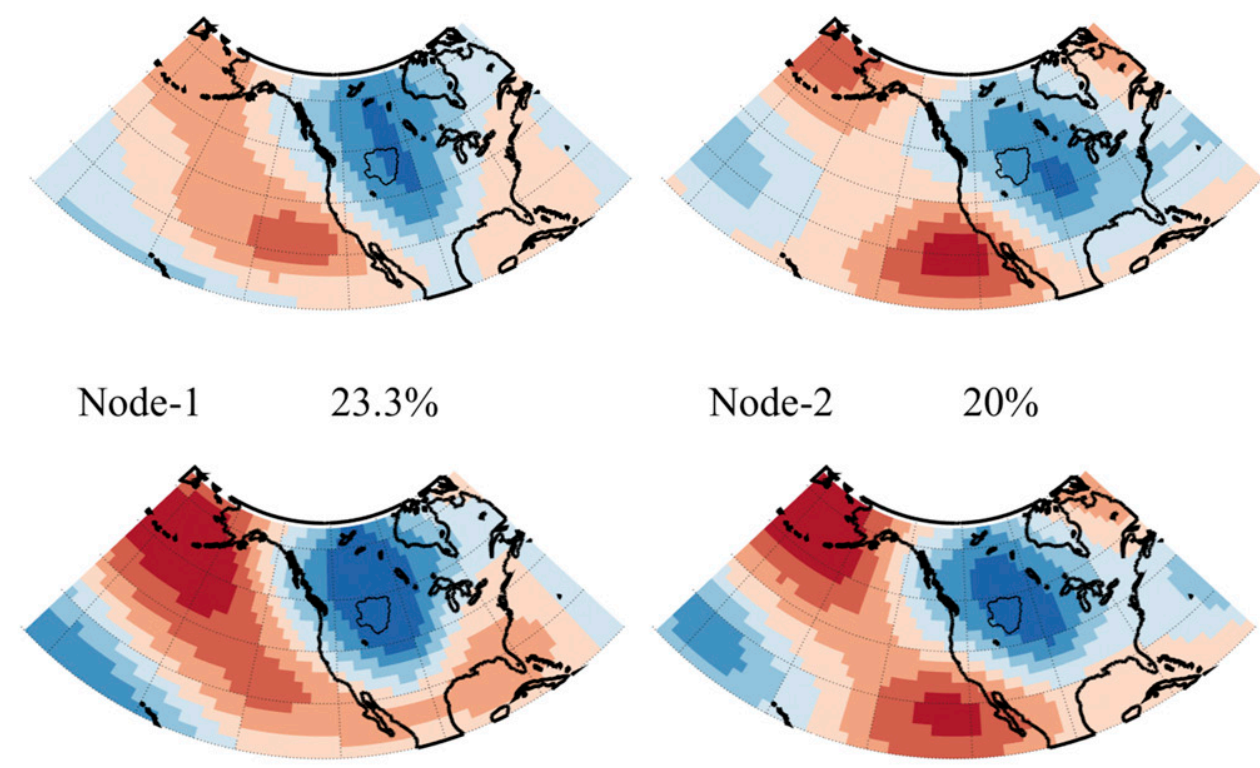

Node-3 $\quad 33.3 \%$

Node-4

$23.3 \%$

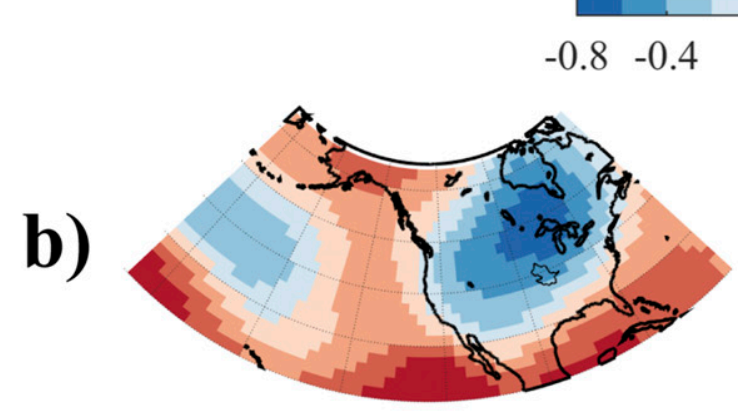

Node-1

$19.4 \%$
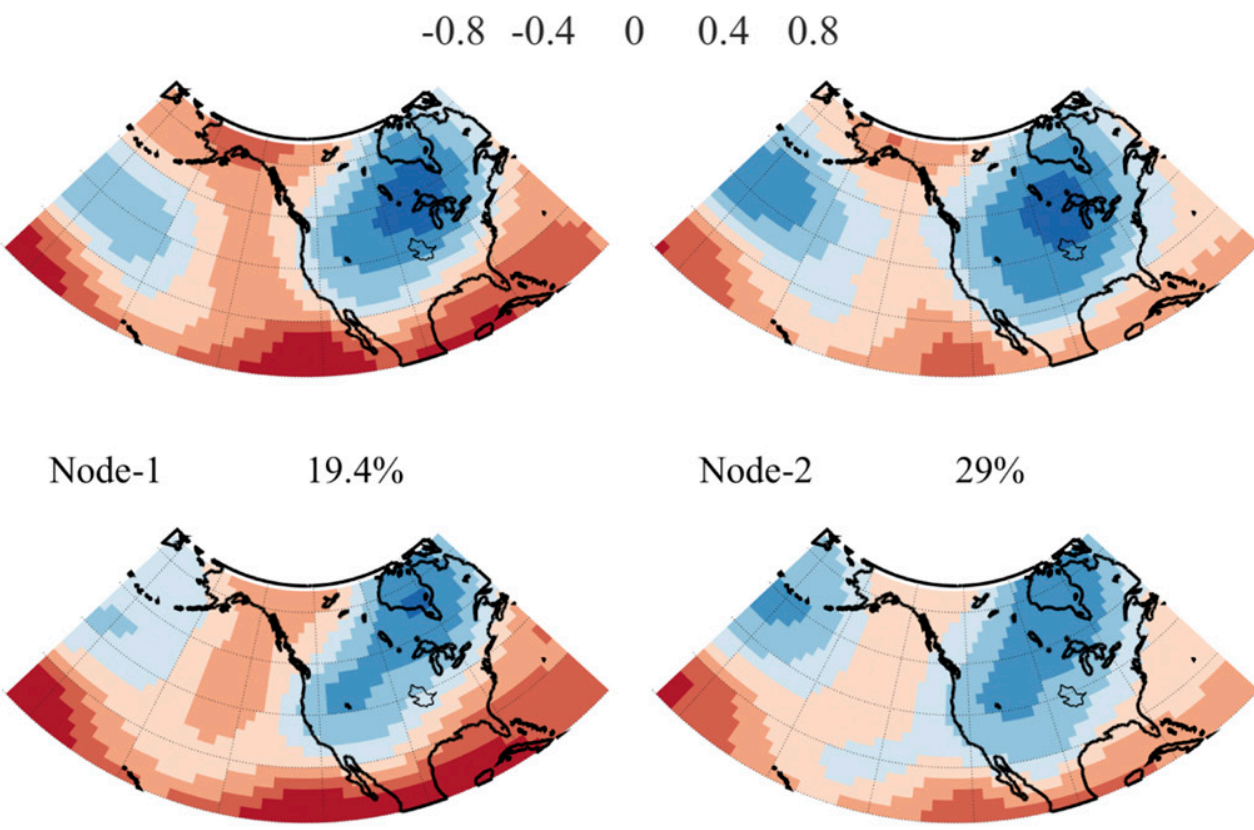

Node-3

$22.6 \%$

Node-2

$29 \%$

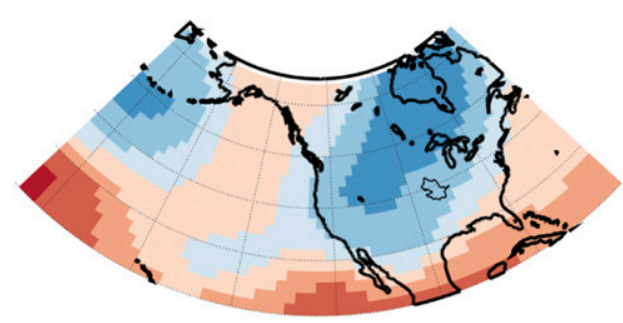

Node-4

$29 \%$

FIG. 8. SOMs showing important patterns in 500-hPa GPH anomalies for (a) the October-January season for years with high flow in the UMRB and (b) the April-July season for years with high flow in the LMRB.

patterns. In the UMRB, this would translate to dry conditions when incoming storms are forced to go around the blocking high. There were only two statistically distinct nodes in the SOM for low-flow years in the
LMRB (Fig. 9b). This subset has weaker GPH patterns than those described in Fig. 9a, which might be expected given the different season, with generally high pressure across much of the United States and western Canada. 


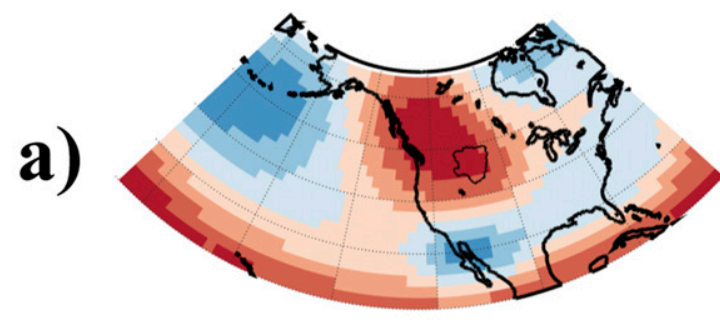

Node-1

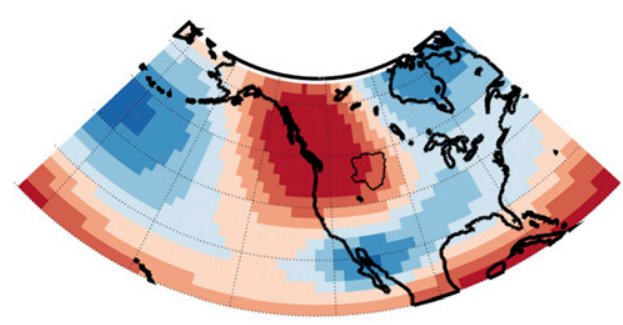

Node-3 $\quad 20 \%$

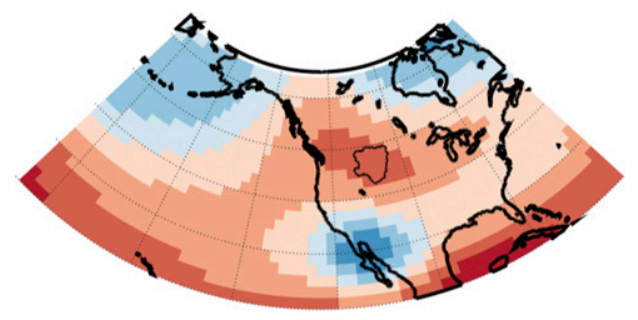

Node-2

$34.3 \%$

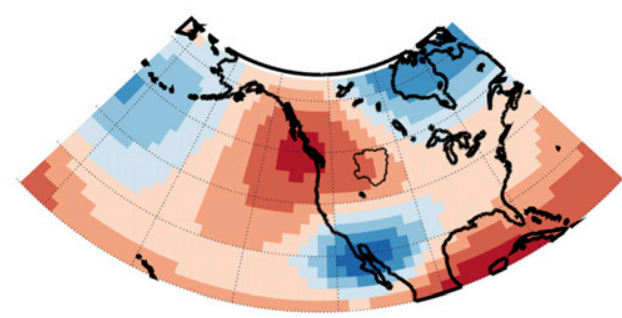

Node-4

$20 \%$

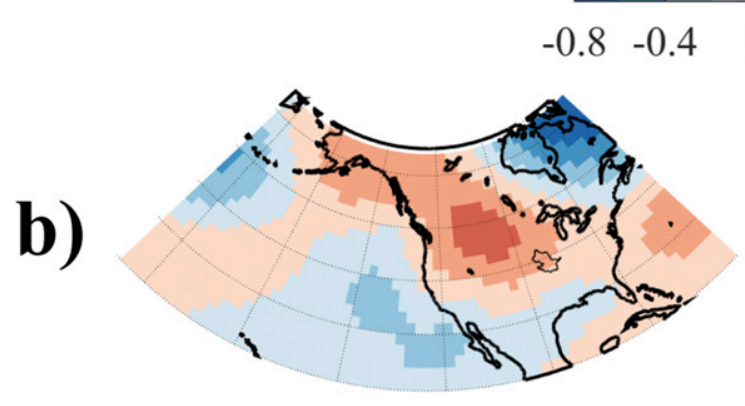

Node-1
$47.4 \%$
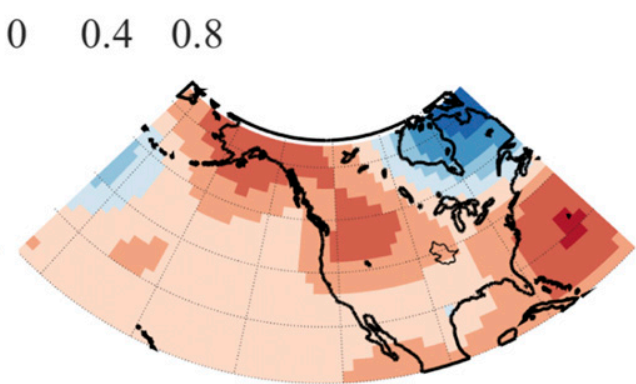

Node-2
$52.6 \%$

FIG. 9. As in Fig. 8, but for years with low flow.

These patterns bear some resemblance to the spatial field correlations between LMRB streamflow and pressure shown in Fig. 7 (node 1 in particular), and again resemble a positive NAO pattern, where high pressure dominates much of the United States and the Atlantic, and low pressure is situated over northeastern Canada and Greenland. High pressure during the April-July time period indicates overall subsidence and stability across the region, which is not conducive to precipitation events.

We conducted two-tailed permutation $t$ tests to assess the association between teleconnection indices suggested in Figs. 7-9 (NPI, PNA, AMO, and SOI) and streamflow in the UMRB and LMRB in the corresponding year and one year prior to the streamflow year (see supplemental material for methods description and data in Tables S1 and S2). There are multiple measures that can be used to describe Atlantic and Pacific Ocean variability. Pacific decadal variability (PDV) is particularly complex and has been described by a number of indices, including the Pacific quasi-decadal oscillation (QDO), the Pacific decadal oscillation (PDO), the North Pacific Gyre Oscillation, and the North Pacific Oscillation. The QDO, a 10-15-yr oscillation associated with Niño-4 region SSTs, has been linked to wet and dry periods in the MRB (Wang et al. 2014). Although we see this periodicity in our streamflow records, it does not appear to be consistent through time and is present only in recent decades (Fig. S3). PDO has also been used as an indicator of North Pacific influence on MRB 
hydroclimate in past research (e.g., Mehta et al. 2011, 2016), but several recent studies have argued against using PDO as a framework for understanding Pacific impacts on climate in teleconnected regions, as PDO appears to result from a combination of different physical processes rather than being a single mode of the climate system (McAfee 2017; Newman et al. 2016). Because correlations between PDO and hydroclimate variables may actually reflect correlations with processes driving both PDO and hydroclimate [i.e., the tropics (measured by ENSO) and the Aleutian low (measured by NPI) (Schneider and Cornuelle 2005; Newman et al. 2016)], here we use the underlying ENSO and NPI indices as measures of PDV. The results of the two-tailed permutation $t$ tests indicate that the North Pacific-based NPI and PNA have the strongest associations with UMRB flow, while the Atlantic-based NAO has the most significant impacts on LMRB flow (Table S3, Fig. S2). In addition, SOI, a measure of the atmospheric component of ENSO (Ropelewski and Jones 1987), has a significant lagged effect on UMRB streamflow, similar to that previously described for the U.S. Pacific Northwest by Redmond and Koch (1991). Understanding these drivers can potentially aid in streamflow forecasting, particularly when there is high persistence in the ocean-atmosphere system or when there are lags between the ocean-atmosphere system and terrestrial hydroclimate (as with ENSO).

\section{b. Changing influence of climate on streamflow}

Given the potential impacts of a changing climate on water resources, we examined trends in streamflow and in the climatic factors most important to flow. While trend analysis is notoriously sensitive to the length of the time series being assessed, here we use the full period common to main gauges and climate data (1912-2011) where possible to evaluate long-term trends. We also assess trends over a shorter period of time in order to include the shorter upper Missouri main stem streamflow record (sum of three gauge records, 1941-2010) and the observational SWE record (1936-2011). Trend analysis was performed on all records using the parametric ordinary least squares (OLS) regression method, with year as the predictor of the streamflow or climate series. We determined statistical significance based on the $t$ statistic of the predictor slope coefficient to determine if the slope was significantly different from zero. Significance was assessed at the $95 \%(p<0.05)$ and $90 \%(p<0.10)$ confidence levels. The choice of climate variables for trend assessment was based on the correlations shown in Fig. 5. In specific cases, when high variability or extreme outliers were suspected to exert undue influence on an OLS regression estimate, the nonparametric Mann-Kendall trend test (Mann 1945; Kendall 1975) and Theil-Sen regression approach (Theil 1950; Sen 1968) were employed. The Theil-Sen nonparametric regression method is highly robust to outliers since the trend line is computed by estimating slopes between all possible pairs of points, then estimating the overall trend using the median of the slopes.

For UMRB flow over the full period, we found a statistically significant negative trend for the Yellowstone River, but not for the Missouri River at Fort Benton (Table 3). Of the key climatic factors influencing UMRB flow (November-January precipitation, MayJune precipitation, and March-July temperatures), only spring temperatures show a significant and positive trend. The shorter record of analysis (1936-2011) also shows a positive trend in spring temperatures for the upper-basin gauges, which would be consistent with a decreasing trend in streamflow. However, over the shorter time period, trends in flow are not evident for the Yellowstone or Missouri at Fort Benton. There is a slight negative trend in the main stem flow, in contrast to the Fort Benton gauge flows, indicating the possible impacts of warmer spring temperatures on the drainages downstream of Fort Benton that also contribute to main stem flow (i.e., Milk and Musselshell Rivers and their tributaries).

In our assessment of trends in MRB snowpack using the parametric OLS regression approach over the period 1936-2011, Missouri headwaters SWE shows a marginally significant $(p<0.10)$ negative trend (Table 3, Fig. 10a). However, there is no significant trend for the Yellowstone headwaters SWE, or when calculated across the entire MRB headwaters area (includes Missouri, Yellowstone, and Platte Basins). While the year 2011 was selected as an end date to be compatible with flow records, this was an extremely high snow year in comparison to events of recent decades. Extending the end date in the OLS trend analysis to 2016 to test for potential outlier influence shows that the Missouri headwaters maintains a significant and slightly stronger negative trend, the entire MRB headwater region shows a marginally significant $(p<0.10)$ negative trend, and the Yellowstone headwaters SWE retains a nonsignificant, negative trend.

The statistical significance calculated using OLS regression may be biased by recent extreme-year events, the high variability in basinwide SWE averages, the start of trend analysis during the 1930s drought period, and uncertainty in the early portion of the record due to a greatly diminished pre-1960 number of observations (Fig. 10a). To address this, we computed the nonparametric Kendall's tau for each of the three observed SWE time series shown in Fig. 10. This analysis 
TABLE 3. Linear temporal trends in hydroclimatic variables for the full analysis period, 1912-2011, and the period corresponding to the start of the SWE record (1936-2011) estimated from parametric OLS regression. The upper Missouri River main stem flow record is slightly shorter (1941-2010). Bold $p$ values indicate statistical significance at a $95 \%$ confidence level, and bold italicized $p$ values indicate significance at a $90 \%$ confidence level. Climate data for the upper basin are from climate subregions 1 and 2; climate data for the lower basin are from subregion 6 (see Fig. 1).

\begin{tabular}{|c|c|c|c|}
\hline & Record period & $t$ statistic & $p$ level \\
\hline \multicolumn{4}{|l|}{ Upper basin } \\
\hline Missouri River at Ft. Benton, MT & 1912-2011 & 0.220 & 0.827 \\
\hline Yellowstone River at Sidney, MT & 1912-2011 & -2.542 & 0.013 \\
\hline Prior Nov-Jan precipitation & 1912-2011 & 0.717 & 0.475 \\
\hline May-Jun precipitation & 1912-2011 & 1.624 & 0.108 \\
\hline Mar-Jul temperature & 1912-2011 & 2.870 & 0.005 \\
\hline Oct-Mar snow fraction & 1912-2011 & -4.097 & 0.000 \\
\hline \multicolumn{4}{|l|}{ Lower basin } \\
\hline Missouri River at Hermann, MO & 1912-2011 & 2.708 & 0.008 \\
\hline Prior Oct-Nov precipitation & 1912-2011 & 1.446 & 0.151 \\
\hline Apr-Jul precipitation & 1912-2011 & 2.122 & 0.036 \\
\hline Apr-Sep temperature & 1912-2011 & -0.900 & 0.371 \\
\hline \multicolumn{4}{|l|}{ Upper basin } \\
\hline Missouri River at Ft. Benton, MT & 1936-2011 & 1.254 & 0.214 \\
\hline Upper Missouri main stem flow ${ }^{\mathrm{a}}$ & 1941-2010 & -1.540 & 0.128 \\
\hline Yellowstone River at Sidney, MT & 1936-2011 & -0.611 & 0.543 \\
\hline Missouri Headwaters SWE & 1936-2011 & -1.790 & 0.077 \\
\hline Yellowstone Headwaters SWE & 1936-2011 & -0.880 & 0.381 \\
\hline Entire MRB SWE & 1936-2011 & -1.517 & 0.134 \\
\hline Prior Nov-Jan precipitation & 1936-2011 & 0.814 & 0.418 \\
\hline May-Jun precipitation & 1936-2011 & 0.526 & 0.601 \\
\hline Mar-Jul temperature & 1936-2011 & 2.013 & 0.048 \\
\hline \multicolumn{4}{|l|}{ Lower basin } \\
\hline Missouri River at Hermann, MO & 1936-2011 & 3.153 & 0.002 \\
\hline Prior Oct-Nov precipitation & 1936-2011 & 1.807 & 0.075 \\
\hline Apr-Jul precipitation & 1936-2011 & 1.419 & 0.160 \\
\hline Apr-Sep temperature & 1936-2011 & -1.760 & 0.083 \\
\hline
\end{tabular}

${ }^{\text {a }}$ Sum of flows from Missouri River at Landusky, MT; Musselshell River at Mosby, MT; and Milk River at Nashua, MT; the equivalent of the Missouri River flow before the confluence with the Yellowstone River.

suggests a moderately significant $(p<0.1)$ negative trend $(\tau=-0.134)$ for the entire basin, a significant $(p<$ $0.05)$ negative trend $(\tau=-0.154)$ in the Missouri Headwaters, and a still nonsignificant negative trend $(\tau=-0.074)$ in the Yellowstone Headwaters $(p=$ $0.349)$. The highly robust Theil-Sen nonparametric regression approach was applied as a final assessment of estimated trends and significance from the OLS and Mann-Kendall results. The estimated trend in negative slope increased significantly for the Yellowstone and the entire MRB Headwaters, with all basins showing highly significant $(p<0.001)$ negative trends in 1 April SWE (Fig. S4). Setting aside the complexities of estimating the slope and significance of trends in snowpack, it is important to note that all estimated trends are negative and will likely become more markedly negative in the coming years as temperatures continue to increase with global warming. Furthermore, significant changes in precipitation form (rain versus snow) are suggested in the water balance model output, with a calculated snow fraction (proportion of October-March total snowfall relative to total precipitation) for subregion 1 exhibiting a significant trend $(p<0.0001)$ toward less snow and more rain over the cool season, particularly since about 1980 (Table 3, Fig. 10b).

At the Missouri River at Hermann gauge in the LMRB, a clear positive trend in total flow is evident over both 1912-2011 and 1936-2011. This is despite some negative flow trends in the UMRB, and it is likely due to increases in precipitation during the main rainfall season, April-July. This trend in precipitation is not significant over the shorter period, but the prior fall (October-November) precipitation does show a significant positive trend over this period. In contrast to the UMRB, there is a negative trend in LMRB temperature from spring through summer (April-September), significant only over the shorter period at $p<0.10$, which may be associated with the trend toward wetter summers. The contribution of UMRB streamflow to the full basin flow has varied from $14 \%$ to $58 \%$ and has been 


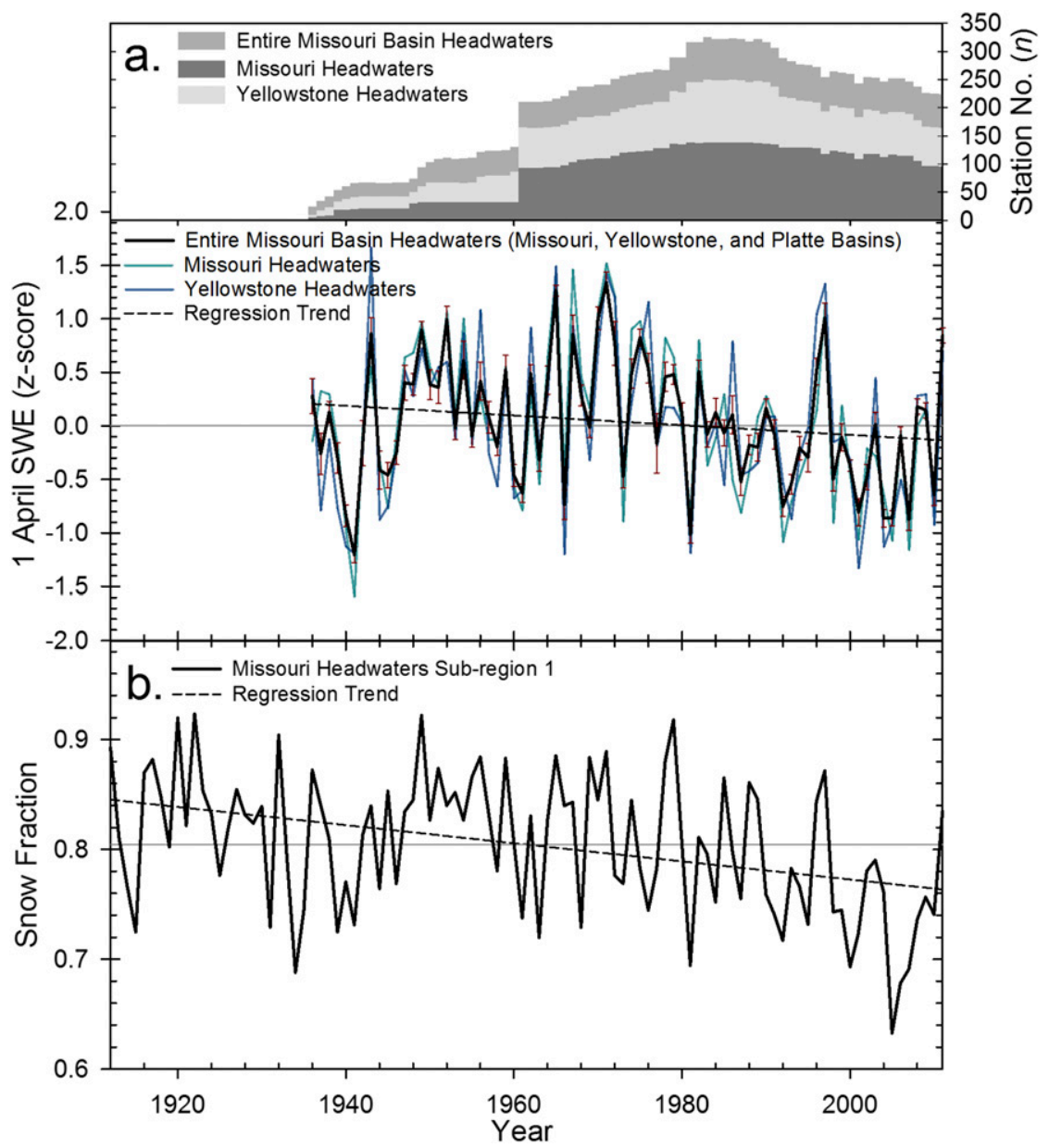

FIG. 10. Trends and variability in (a) observed 1 April SWE summarized at a variety of headwaters basin scales and (b) modeled proportions of snow vs rain ratios (i.e., snow fraction) for the Missouri Headwaters subregion 1. Observed basinwide averages of 1 April SWE are displayed for all observation years (1936-2011), along with the number of NRCS SNOTEL stations and manual snow course observations informing SWE estimates in each basin in (a). Standard error bars are shown in dark red for the estimated SWE values for the entire MRB headwaters basin. Water balance-simulated time series of subregion 1 average snow fractions were computed as October-March snow totals divided by total precipitation. Horizontal solid gray lines indicate the long-term mean for each cluster, and dashed black lines indicate longterm linear trends.

decreasing over the past 70 years (trend significant at $p<0.01$; Fig. 11). This trend is not surprising, given the upper- and lower-basin trends cited above. The greater contribution of LMRB flows to total MRB flow, associated with increases in LMRB precipitation, is overriding any impact of warming temperatures and decreasing flows or SWE in the UMRB on total MRB flow, at least to this point in time.

To gain additional insights on these trends, we evaluated the water balance outputs for subregion 1 in the UMRB and LMRB subregion 6 (1912-2011). The water balance time series for the headwaters subregion 1 shows significant positive trends in water-year potential and actual evapotranspiration $\left[0.26 \mathrm{~mm} \mathrm{yr}^{-1}(p<0.01)\right.$ and $0.23 \mathrm{~mm} \mathrm{yr}^{-1}(p<0.05)$, respectively; Figs. 12e,g], likely related to significant increases in temperature $(p<0.01 ;$ Fig. 12a). In contrast, water-year potential and actual evapotranspiration in the LMRB do not indicate statistically significant trends (Figs. 12f,h). In agreement with the observed data, statistically significant $(p<0.05)$ positive trends are evident in LMRB water-year precipitation and runoff (Figs. 12d,j). These long-term positive trends in precipitation and runoff may be controlled, in part, by increases in precipitation and runoff near 1970 (Fig. 12d) that have been identified in previous studies (McCabe and Wolock 2002). Because of 


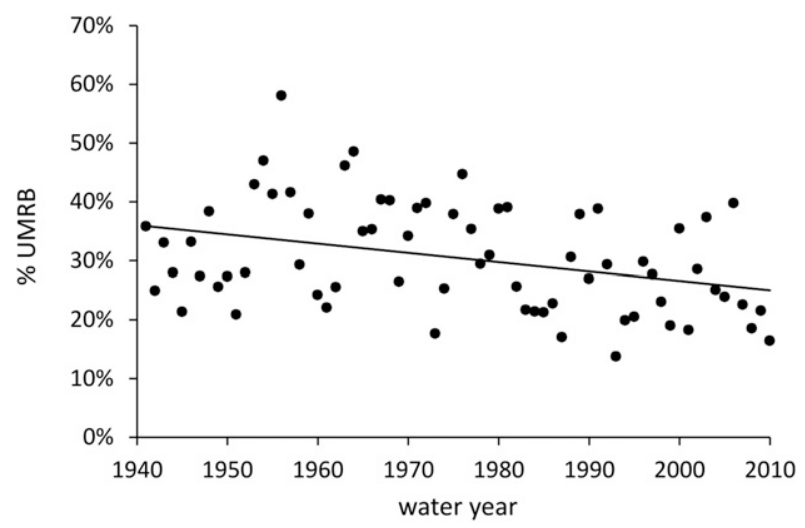

FIG. 11. Percent of total MRB flow accounted for by upper basin flow, 1941-2010. Upper basin flow is the sum of flow at the following gauges: Missouri River at Landusky, Musselshell River at Mosby, Milk River at Nashua, and Yellowstone at Sidney. The solid black line indicates the long-term linear trend.

the high variability of these time series and recent extreme events, we tested the significance of these trends with a nonparametric approach. Results from the nonparametric Mann-Kendall test indicate that the same time series shown with significant trends in Fig. 12 remained significant. The only exception was for precipitation in subregion 6 , which had an estimated $p$ value of $0.059(\tau=0.128)$ (compared to $<0.05$ as suggested by OLS regression).

\section{Discussion}

The analyses presented in this paper are intended to provide a detailed examination of the hydroclimate of the MRB, which has not been previously reported. We found that MRB subregions 1 and 6, representing the uppermost and lowermost portions of the basin (Fig. 1), are the most important source regions for MRB flow. These are the only subregions where precipitation exceeds potential evapotranspiration (PET) in the cool season. In the other parts of the basin, PET is nearly equal to or greater than precipitation for almost all months (Fig. 2). This suggests that climatic variability impacting the uppermost and lowermost parts of the basin (subregions 1 and 6; Fig. 1) is the most important control on total MRB outflow. Since subregion 6 , the lowest portion of the basin near the mouth, contributes $44 \%$ of the total MRB flow, local climate conditions in this subregion exert a particularly strong influence on total outflow.

On average, the UMRB accounts for slightly more than a quarter of the total MRB flow, which is much less than the upper basins of most major rivers in the western United States (e.g., the Colorado River), where snowpack is the main source of water supply (Dettinger et al. 2015). However, the UMRB contribution ranges from $14 \%$ to $>50 \%$ in any given year (Fig. 11). In the UMRB itself, about half of the flow comes from snowmelt-dominated basins (Missouri, Yellowstone, and Bighorn) draining mountain ranges in southwestern Montana and northeastern Wyoming. To put this into context, the drainage area of the three headwaters source regions together is slightly less than $9600 \mathrm{~km}^{2}$, about $23 \%$ of the area of the UMRB, but contributes over half of the total flow in the UMRB. Of particular note, the upper Yellowstone River drains $4 \%$ of the Yellowstone drainage, but its gauge at Corwin Springs accounts for $21 \%$ of total flow. Consequently, these high headwaters are extremely important to upper-basin water supplies, and in some years, also critically important to the full basin. For example, over the years 1953-57, UMRB flows averaged $46 \%$ of total flow (Fig. 11). This was a time period during which Missouri River flow at Hermann was slightly less than $60 \%$ of average. Without the contribution of the UMRB flows, which were close to average over these years, low-flow conditions in the LMRB could have been much worse. As 1 April SWE is the most important predictor of headwaters gauges, these results highlight the key role that winter precipitation and snowpack play not only for UMRB surface water supply variability, but also for the whole MRB in some years.

From a climatological perspective, the seasonality of precipitation in the UMRB and LMRB is very similar, with a peak in precipitation in both regions in June (Fig. 4). This reflects the importance of the springtime flow of moisture from the Gulf of Mexico throughout the MRB. Although a few previous studies (e.g., Najibi et al. 2017) have linked MRB flow conditions with oceanatmosphere teleconnections such as the PNA, other studies have found little to no connection. Here, we found that, because of the different seasonal controls on flow in the UMRB versus the LMRB, it is important to consider the two separately for this type of assessment. The UMRB is largely dependent on winter precipitation conveyed from the Pacific Ocean by westerly flow, and UMRB flow is most strongly associated with changes in the Aleutian low and meridional versus zonal flow conditions described by the PNA and NPI. The LMRB is influenced by precipitation year-round but particularly in the spring and early summer. Our results show that it is most closely associated with Atlantic Ocean circulation changes described by the NAO, which affects warm season moisture flow from the Gulf of Mexico and into the central United States.

Trend analysis documents two main changes over the period of instrumental records: 1) LMRB flows are 
Sub-region 1
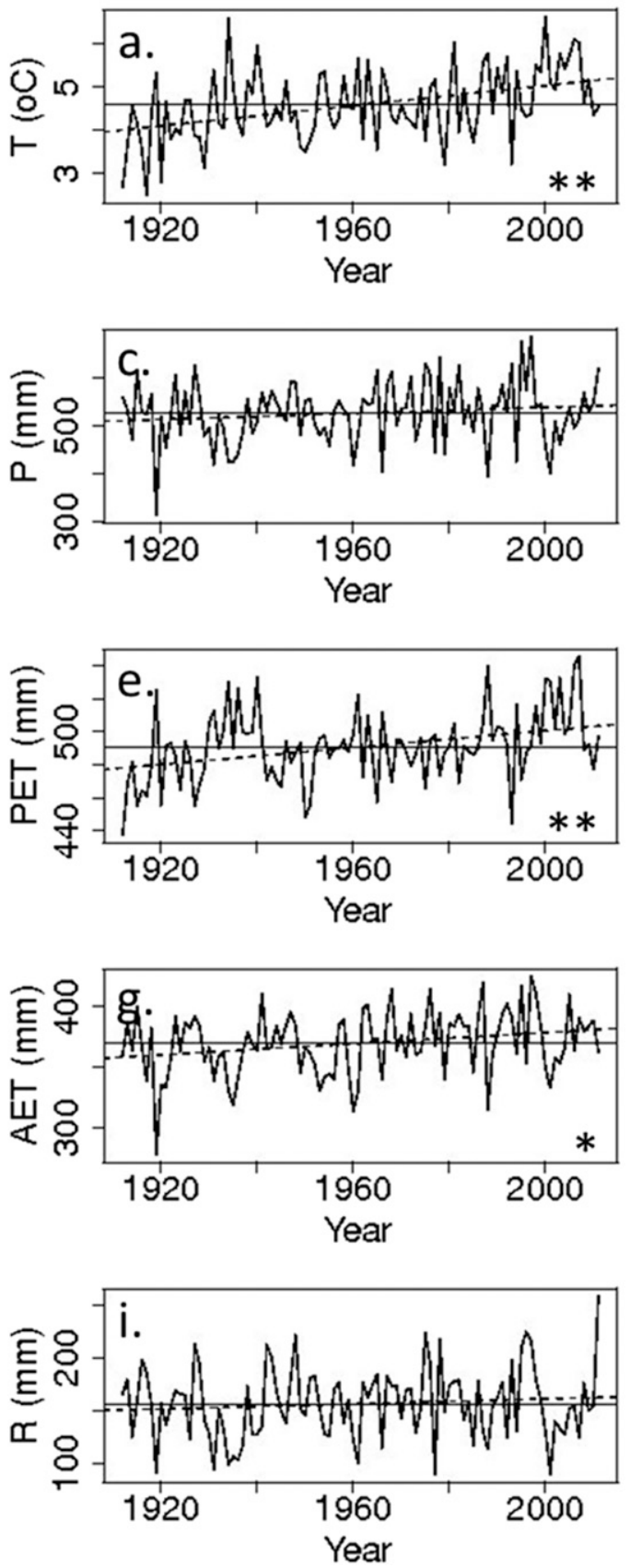

Sub-region 6
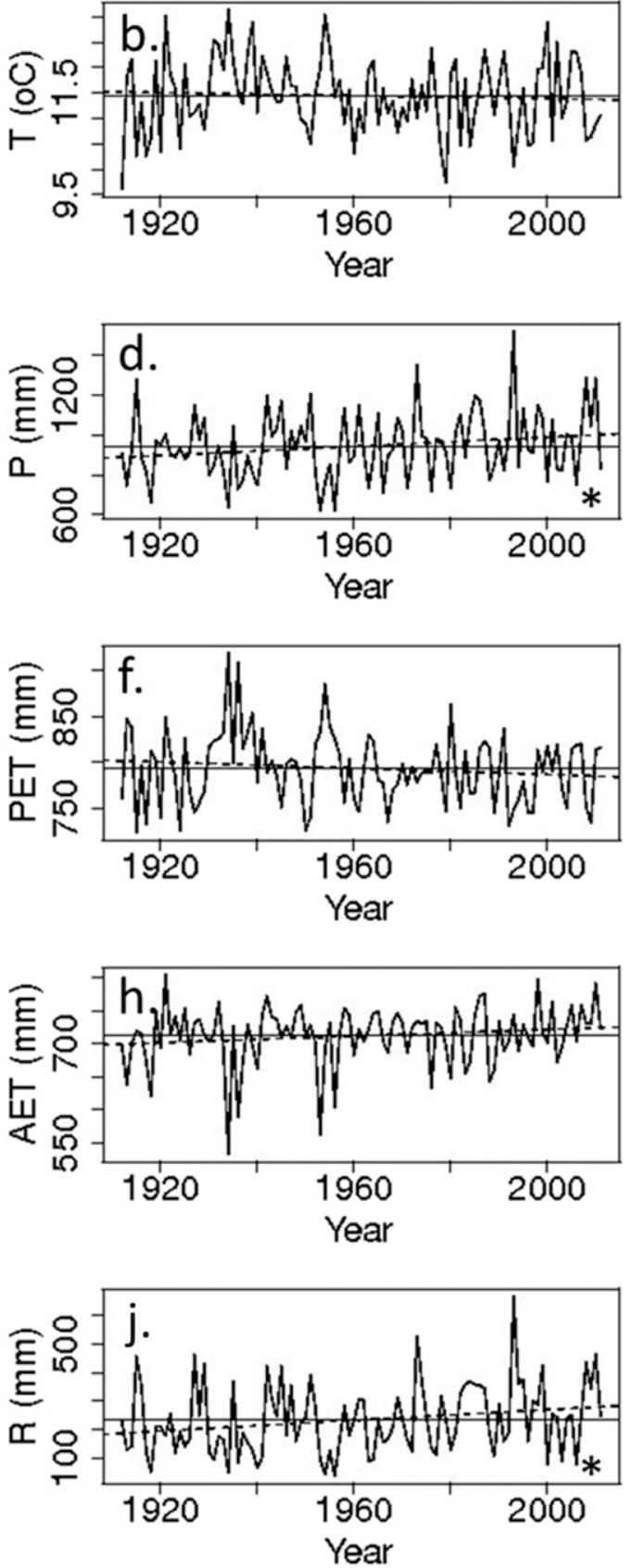

FIG. 12. Time series of mean water-year temperature $T\left({ }^{\circ} \mathrm{C}\right)$, total water-year precipitation $P(\mathrm{~mm})$, PET $(\mathrm{mm})$, AET $(\mathrm{mm})$, and runoff $R(\mathrm{~mm})$ for subregions 1 and 6. Horizontal solid black lines indicate the long-term mean for each variable, and dashed black lines indicate long-term linear trends. Long-term trends that are statistically significant at a $95 \%(*)$ or $99 \%(* *)$ confidence level are indicated in the lower right-hand corner of each plot.

increasing and 2) March-July temperatures in the UMRB are increasing. Increases in LMRB flow are consistent with prior work, which reported strong wetting trends over South Dakota and the eastern third of the LMRB since 1975 and higher flows in the eastern MRB (Norton et al. 2014; Livneh et al. 2016). These trends are occurring in concert with cooling trends over the warm season for the 1936-2011 time period. 
In contrast, increasing temperatures in the UMRB, where snowpack is a key source of streamflow, are occurring with some decreases in flow and snowpack (e.g., Yellowstone River flows over 1912-2011; 1 April SWE over 1936-2011). High year-to-year variability, along with periods of droughts and wetness, make trend detection more difficult in moisture-related variables. For example, SWE data start in the 1930s, which is a period of drought in the UMRB, biasing trend analysis. Pederson et al. (2011b) found that midelevation snowpack in the northern Rocky Mountain region has decreased since 1969 , likely related to increasing spring temperatures, while Norton et al. (2014) documented decreasing flows in the western and southern subbasins of the MRB over the past 50 years. While the 1 April SWE trends are all negative, but not always statistically significant, snow fraction for the subregion 1 portion of the UMRB does indicate a significant decrease in the amount of snowfall in the cool season relative to overall precipitation (this result also holds true for subregions 2 and 3). These results strongly suggest that UMRB snowpack and streamflow are decreasing, and will continue to do so, under warming spring temperatures that also serve to increase water loss through evapotranspiration. When considered along with the decreasing trend in contribution of UMRB flows to total MRB streamflow (Fig. 11), it is likely that upper-basin flows will less often provide important supplements to the lower basin, as occurred in the 1950s. The implications are more sobering for the UMRB, where decreasing flows will impact a region with growing and competing water needs.

The MRB is a hydroclimatically complex basin, with two main source regions that are under the influence of very different sets of climatic controls. Understanding how these different controls will be modified by a changing climate is critical for anticipating future flows and the potential for floods and droughts. This study is not comprehensive, and additional work is needed to investigate the parts of the basin not addressed here. Future research will also be needed to examine the complexities of MRB climate-streamflow interactions, including rain-on-snow events, complex groundwatersurface water interactions, ocean-atmosphere teleconnection interactions and their regional impacts, and the drivers of high and low flows across all subregions. The results presented here will provide a baseline for further assessment of hydroclimate extremes and the effects of climate change in the MRB.

Acknowledgments. This work was supported by the National Science Foundation Paleo Perspectives on Climate Change (P2C2) program through Grants AGS1403957 and AGS-1401549. We thank Sarah Fredrick for assistance with the climate analysis and Justin Martin for helping compile, update, and screen the naturalized monthly streamflow records. Any use of trade, firm, or product names is for descriptive purposes only and does not imply endorsement by the U.S. Government.

\section{REFERENCES}

Barnhart, T. B., N. P. Molotch, B. Livneh, A. A. Harpold, J. F. Knowles, and D. Schneider, 2016: Snowmelt rate dictates streamflow. Geophys. Res. Lett., 43, 8006-8016, https://doi.org/ 10.1002/2016GL069690.

Barnston, A. G., and R. E. Livezey, 1987: Classification, seasonality and persistence of low-frequency atmospheric circulation patterns. Mon. Wea. Rev., 115, 1083-1126, https://doi.org/ 10.1175/1520-0493(1987)115<1083:CSAPOL >2.0.CO;2.

Cary, L. E., and C. Parrett, 1996: Synthesis of natural flows at selected sites in the upper Missouri River basin, Montana, 1928-89. USGS Water Resources Investigations Rep. 95-4261, 114 pp., https://pubs.usgs.gov/wri/1995/4261/ report.pdf.

Chase, K. J., 2014: Streamflow statistics for unregulated and regulated conditions for selected locations on the Upper Yellowstone and Bighorn Rivers, Montana and Wyoming, 1928-2002. USGS Scientific Investigations Rep. 2014-5115, 117 pp., http://dx.doi.org/10.3133/sir20145115.

Coleman, J. S. M., and D. Budikova, 2013: Eastern U.S. summer streamflow during extreme phases of the North Atlantic oscillation. J. Geophys. Res. Atmos., 118, 4181-4193, https:// doi.org/10.1002/jgrd.50326.

Compo, G. P., and Coauthors, 2011: The Twentieth Century Reanalysis Project. Quart. J. Roy. Meteor. Soc., 137, 1-28, https:// doi.org/10.1002/qj. 776.

Daly, C., M. Halbleib, J. I. Smith, W. P. Gibson, M. K. Doggett, G. H. Taylor, J. Curtis, and P. P. Pasteris, 2008: Physiographically sensitive mapping of climatological temperature and precipitation across the conterminous United States. Int. J. Climatol., 28, 2031-2064, https://doi.org/10.1002/joc.1688.

Dettinger, M., B. Udall, and A. Georgakakos, 2015: Western water and climate change. Ecol. Appl., 25, 2069-2093, https:// doi.org/10.1890/15-0938.1.

Enfield, D. B., A. M. Mestas-Nunez, and P. J. Trimble, 2001: The Atlantic multidecadal oscillation and its relation to rainfall and river flows in the continental US. Geophys. Res. Lett., 28, 2077-2080, https://doi.org/10.1029/2000GL012745.

Galat, D. L., C. R. Berry, E. J. Peters, and R. G. White, 2005: Missouri River basin. Rivers of North America, A. C. Benke and C. E. Cushing, Eds., Elsevier Academic Press, 427-480.

Gray, S. T., and G. J. McCabe, 2010: Combined water balance and tree-ring approaches to understanding the potential hydrologic effects of climate change on the Yellowstone River. Water Resour. Res., 46, W05513, https://doi.org/10.1029/ 2008WR007650.

Haj, A. E., D. E. Christiansen, and R. J. Viger, 2014: The effects of Missouri River mainstem reservoir system operations on 2011 flooding using a precipitation-runoff modeling system model. USGS Professional Paper 1798-K, 33 pp, https://pubs. usgs.gov/pp/1798k/pdf/pp1798k.pdf.

Henderson, K. G., and P. J. Robinson, 1994: Relationships between the Pacific/North American teleconnection patterns and precipitation events in the south-eastern USA. Int. J. Climatol. 14, 307-323, https://doi.org/10.1002/joc.3370140305. 
Hewitson, B. C., and R. G. Crane, 2002: Self-organizing maps: Applications to synoptic climatology. Climate Res., 22, 13-26, https://doi.org/10.3354/cr022013.

Hoerling, M., J. Eischeid, and R. Webb, 2013: Understanding and explaining climate extremes in the Missouri River basin associated with the 2011 flooding. NOAA Climate Assessment Rep. to USACE, 34 pp., https://www.esrl.noaa.gov/psd/csi/ factsheets/pdf/noaa-mrb-climate-assessment-report.pdf.

,$- \ldots$, A. Kumar, R. Leung, A. Mariotti, K. Mo, S. Schubert, and R. Seager, 2014: Causes and predictability of the 2012 great plains drought. Bull. Amer. Meteor. Soc., 95, 269-282, https://doi.org/10.1175/BAMS-D-13-00055.1.

Hu, Q., S. Feng, and R. J. Oglesby, 2011: Variations in North American summer precipitation driven by the Atlantic multidecadal oscillation. J. Climate, 24, 5555-5570, https://doi.org/ 10.1175/2011JCLI4060.1.

Hurrell, J. W., 1995: Decadal trends in the North Atlantic Oscillation: Regional temperatures and precipitation. Science, 269, 676-679, https://doi.org/10.1126/science.269.5224.676.

Johnson, N. C., 2013: How many ENSO flavors can we distinguish? J. Climate, 26, 4816-4827, https://doi.org/10.1175/ JCLI-D-12-00649.1.

Jones, P. D., T. Jonsson, and D. Wheeler, 1997: Extension to the North Atlantic oscillation using early instrumental pressure observations from Gibraltar and south-west Iceland. Int. J. Climatol., 17, 1433-1450, https://doi.org/10.1002/(SICI)1097-0088(19971115)17: 13<1433::AID-JOC203>3.0.CO;2-P.

Kendall, M. G., 1975: Rank Correlation Methods. 4th ed. Charles Griffin, 202 pp.

Lettenmaier, D. P., A. W. Wood, R. N. Palmer, E. F. Wood, and E. Z. Stakhiv, 1999: Water resources implications of global warming: a U.S. regional perspective. Climatic Change, 43, 537-579, https://doi.org/10.1023/A:1005448007910.

Livneh, B., M. P. Hoerling, A. Badger, and J. Eischeid, 2016: Causes for hydrologic extremes in the upper Missouri River basin. NOAA Climate Assessment Rep. to USACE, 39 pp., https://www.drought.gov/drought/sites/drought.gov.drought/files/ 2016-mrb-climate-assessment-report-final.pdf.

Malevich, S. B., and C. A. Woodhouse, 2017: Pacific sea surface temperatures, midlatitude atmospheric circulation, and widespread interannual anomalies in western U.S. streamflow. Geophys. Res. Lett., 44, 5123-5132, https://doi.org/10.1002/ 2017 GL073536.

Mann, H. B., 1945: Nonparametric tests against trend. Econometrica, 13, 245-259, https://doi.org/10.2307/1907187.

Maurer, E. P., and D. P. Lettenmaier, 2004: Potential effects of long-lead hydrologic predictability on Missouri River mainstem reservoirs. J. Climate, 17, 174-186, https://doi.org/ 10.1175/1520-0442(2004)017<0174:PEOLHP>2.0.CO;2.

McAfee, S. A., 2017: Uncertainty in Pacific decadal oscillation indices does not contribute to teleconnection instability. Int. J. Climatol., 37, 3509-3516, https://doi.org/10.1002/joc.4918.

McCabe, G. J., and D. M. Wolock, 2002: A step increase in streamflow in the conterminous United States. Geophys. Res. Lett., 29, 2185, https://doi.org/10.1029/2002GL015999.

—_ and _ 2008: Joint variability of global runoff and global sea-surface temperatures. J. Hydrometeor., 9, 816-824, https:// doi.org/10.1175/2008JHM943.1.

— , and —, 2011a: Century-scale variability in global annual runoff examined using a water balance model. Int. J. Climatol., 31, 1739-1748, https://doi.org/10.1002/joc.2198.

$\longrightarrow$, and — 2011b: Independent effects of temperature and precipitation on modeled runoff in the conterminous United
States. Water Resour. Res., 47, W11522, https://doi.org/ 10.1029/2011WR010630.

-, M. A. Palecki, and J. L. Betancourt, 2004: Pacific and Atlantic Ocean influences on multidecadal drought frequency in the United States. Proc. Natl. Acad. Sci. USA, 101, 4136-4141, https://doi.org/10.1073/pnas.0306738101.

Mehta, V. M., N. J. Rosenberg, and K. Mendoza, 2011: Simulated impacts of three decadal climate variability phenomena on water yields in the Missouri River basin. J. Amer. Water Resour. Assoc., 47, 126-135, https://doi.org/10.1111/ j.1752-1688.2010.00496.x.

, C. L. Knutson, N. J. Rosenberg, J. R. Olsen, N. A. Wall, T. K. Bernadt, and M. J. Hayes, 2013: Decadal climate information needs of stakeholders for decision support in water and agriculture production sectors: A case study in the Missouri River basin. Wea. Climate Soc., 5, 27-42, https://doi.org/10.1175/ WCAS-D-11-00063.1.

, K. Mendoza, P. Daggupati, R. Srinivasan, N. J. Rosenberg, and D. Deb, 2016: High-resolution simulations of decadal climate variability impacts on water yield in the Missouri River basin with the Soil and Water Assessment Tool (SWAT). J. Hydrometeor., 17, 2455-2476, https://doi.org/ 10.1175/JHM-D-15-0039.1.

Najibi, N., N. Devineni, and M. Lu, 2017: Hydroclimate drivers and atmospheric teleconnections of long duration floods: An application to large reservoirs in the Missouri River basin. Adv. Water Resour., 100, 153-167, https://doi.org/10.1016/ j.advwatres.2016.12.004.

Newman, M., and Coauthors, 2016: The Pacific decadal oscillation, revisited. J. Climate, 29, 4399-4427, https://doi.org/10.1175/ JCLI-D-15-0508.1.

Norton, P. A., M. T. Anderson, and J. F. Stamm, 2014: Trends in annual, seasonal, and monthly streamflow characteristics at 227 streamgages in the Missouri River watershed, water years 1960-2011. USGS Scientific Investigations Rep. 2014-5053, 128 pp., https://pubs.usgs.gov/sir/2014/5053/pdf/sir2014-5053.pdf.

Olsen, J. R., J. R. Stedinger, N. C. Matalas, and E. Z. Stakhiu, 1999: Climate variability and flood frequency estimation for the upper Mississippi and lower Missouri Rivers. J. Amer. Water Resour. Assoc., 35, 1509-1523, https://doi.org/10.1111/ j.1752-1688.1999.tb04234.x.

Oyler, J. W., S. Z. Dobrowski, A. P. Ballantyne, A. E. Klene, and S. W. Running, 2015a: Artificial amplification of warming trends across the mountains of the western United States. Geophys. Res. Lett., 42, 153-161, https://doi.org/10.1002/2014GL062803.

A. Ballantyne, K. Jencso, M. Sweet, and S. W. Running, 2015b: Creating a topoclimatic daily air temperature dataset for the conterminous United States using homogenized station data and remotely sensed land skin temperature. Int. J. Climatol., 35, 2258-2279, https://doi.org/10.1002/joc.4127.

Pederson, G. T., and Coauthors, 2011a: The unusual nature of recent snowpack declines in the North American cordillera. Science, 333, 332-335, https://doi.org/10.1126/science.1201570.

—, S. T. Gray, T. Ault, W. Marsh, D. B. Fagre, A. G. Bunn, C. A. Woodhouse, and L. J. Graumlich, 2011b: Climatic controls on the snowmelt hydrology of the northern Rocky Mountains. J. Climate, 24, 1666-1687, https://doi.org/10.1175/2010JCLI3729.1.

, J. L. Betancourt, and G. J. McCabe, 2013: Regional patterns and proximal causes of the recent snowpack decline in the Rocky Mountains, U.S. Geophys. Res. Lett., 40, 1811-1816, https://doi.org/10.1002/grl.50424.

Qiao, L., Z. Pan, R. B. Herrmann, and Y. Hong, 2014: Hydrological variability and uncertainty of lower Missouri River basin under 
changing climate. J. Amer. Water Resour. Assoc., 50, 246-260, https://doi.org/10.1111/jawr.12126.

Redmond, K. T., and R. W. Koch, 1991: Surface climate and streamflow variability in the western United States and their relationship to large-scale circulation indices. Water Resour. Res., 27, 2381-2399, https://doi.org/10.1029/91WR00690.

Rex, D. F., 1950: Blocking action in the middle troposphere and its effect upon regional climate. Tellus, 2, 196-211, https:// doi.org/10.1111/j.2153-3490.1950.tb00331.x.

Ropelewski, C. F., and P. D. Jones, 1987: An extension of the Tahiti-Darwin Southern Oscillation index. Mon. Wea. Rev., 115, 2161-2165, https://doi.org/10.1175/1520-0493(1987)115<2161: AEOTTS $>2.0 . C O ; 2$.

Ruiz-Barradas, A., and S. Nigam, 2005: Warm season rainfall variability over the U.S. Great Plains in observations, NCEP and ERA-40 reanalyses, and NCAR and NASA atmospheric model simulations. J. Climate, 18, 1808-1830, https://doi.org/10.1175/JCLI3343.1.

Schneider, N., and B. D. Cornuelle, 2005: The forcing of the Pacific decadal oscillation. J. Climate, 18, 4355-4373, https://doi.org/ 10.1175/JCLI3527.1.

Sen, P. K., 1968: Estimates of regression coefficient based on Kendall's tau. J. Amer. Stat. Assoc., 63, 1379-1389, https:// doi.org/10.1080/01621459.1968.10480934.

Smith, T. M., R. W. Reynolds, T. C. Peterson, and J. Lawrimore, 2008: Improvements to NOAA's historical merged landocean surface temperature analysis (1880-2006). J. Climate, 21, 2283-2296, https://doi.org/10.1175/2007JCLI2100.1.

Theil, H., 1950: A rank-invariant method for linear and polynomial regression analysis. Proc. K. Ned. Akad. Wet., Ser. A, 53, 386-392, 512-525, 1397-1412.
Trenberth, K. E., and J. W. Hurrell, 1994: Decadal atmosphereocean variations in the Pacific. Climate Dyn., 9, 303-319, https://doi.org/10.1007/BF00204745.

U.S. Bureau of Reclamation, 2012: St. Mary River and Milk River basins study summary report. USBR Rep., 37 pp, https:// www.usbr.gov/watersmart/bsp/docs/finalreport/Milk-StMary/ Milk-StMary_SummaryReport.pdf.

U.S. Department of Agriculture, 1994: State Soil Geographic (STATSGO) data base: Data use information. USDA Miscellaneous Publ. 1492, 113 pp.

Wallace, J. M., and D. S. Gutzler, 1981: Teleconnections in the geopotential height field during the Northern Hemisphere Winter. Mon. Wea. Rev., 109, 784-812, https://doi.org/10.1175/ 1520-0493(1981)109<0784:TITGHF>2.0.CO;2.

Wang, S.-Y., K. Hakala, R. R. Gillies, and W. J. Capehart, 2014: The Pacific quasidecadal oscillation (QDO): An important precursor toward anticipating major flood events in the Missouri River basin? Geophys. Res. Lett., 41, 991-997, https:// doi.org/10.1002/2013GL059042.

Weaver, S. J., and S. Nigam, 2008: Variability of the Great Plains low-level jet: Large-scale circulation context and hydroclimate impacts. J. Climate, 21, 1532-1551, https://doi.org/10.1175/ 2007JCLI1586.1.

Wilks, D. S., 2006: On "field significance" and the false discovery rate. J. Appl. Meteor. Climatol., 45, 1181-1189, https://doi.org/ 10.1175/JAM2404.1.

Wise, E. K., 2010: Spatiotemporal variability of the precipitation dipole transition zone in the western United States. Geophys. Res. Lett., 37, L07706, https://doi.org/ 10.1029/2009GL042193. 